Review

\title{
Micro-Level Management of Agricultural Inputs: Emerging Approaches
}

\author{
Jonathan Weekley ${ }^{1}$, Joseph Gabbard ${ }^{2}$ and Jerzy Nowak ${ }^{1, *}$
}

1 Department of Horticulture, Virginia Polytechnic Institute and State University, Blacksburg, VA 24061, USA; E-Mail: jweekley@vt.edu

2 Virginia Bioinformatics Institute, Virginia Polytechnic Institute and State University, Blacksburg, VA 24061, USA; E-Mail: jgabbard@vt.edu

* Author to whom correspondence should be addressed; E-Mail: jenowak@vt.edu; Tel.: +1-540-231-2663; Fax: +1-540-231-3083.

Received: 19 October 2012; in revised form: 8 December 2012 / Accepted: 10 December 2012 / Published: 18 December 2012

\begin{abstract}
Through the development of superior plant varieties that benefit from high agrochemical inputs and irrigation, the agricultural Green Revolution has doubled crop yields, yet introduced unintended impacts on environment. An expected 50\% growth in world population during the 21 st century demands novel integration of advanced technologies and low-input production systems based on soil and plant biology, targeting precision delivery of inputs synchronized with growth stages of crop plants. Further, successful systems will integrate subsurface water, air and nutrient delivery, real-time soil parameter data and computer-based decision-making to mitigate plant stress and actively manipulate microbial rhizosphere communities that stimulate productivity. Such an approach will ensure food security and mitigate impacts of climate change.
\end{abstract}

Keywords: agro-biosystem management; smart field; low-input/low-impact agriculture; precision delivery 


\section{Introduction}

\subsection{Ecosystem Degradation and Resource Depletion}

Though modern agricultural management practices developed during the 20th century, i.e., the Green Revolution, have facilitated production intensification that has supported an ever-increasing world population through advancement, integration, and utilization of mechanized equipment, modern cultivars ("super varieties"), irrigation, and agrochemical inputs, millions of hectares of converted land, and environmental and human health, have been negatively affected [1]. Of the $37 \%$ of Earth's surface presently under cultivation [2], at least $17 \%$ has experienced some form of soil degradation since 1945 [3], an area approximately twice that of the United States of America. This soil degradation is frequently the result of water, wind, and chemical erosion, and the deterioration of soil physical properties associated with intensive agricultural practices [4].

The degradation of aquatic ecosystems through the construction of water diversion structures, soil erosion, and salt and nutrient loading has contributed to a generally negative public attitude toward irrigation in production agriculture $[3,5,6]$. Water withdrawal structures (e.g., dams, canals, and wells) lower stream levels and disrupt aquatic migratory animals. Approximately $20 \%$ of irrigation sourced from ground water is used in excess of recharge [3]. Erosion contributes to soil degradation that causes the loss of productive farm land and leads to sediment buildup in watersheds. Increases in sediment load from soil erosion also negatively affects irrigation efficiency through the clogging of downstream water delivery systems; reducing reservoir storage capacities, increasing maintenance costs, and ultimately reducing production capacities [7]. In addition, application of excessive irrigation frequently leads to anaerobic soil conditions that increase greenhouse gas emissions (i.e., $\mathrm{CH}_{4}, \mathrm{~N}_{2} \mathrm{O}$, and NO) $[5,8]$.

Low crop use-efficiencies for both water and agrochemicals have led to water resource depletion, aquatic ecosystem degradation, and increased greenhouse gas emissions from arable lands. A growing reliance on chemical fertilizers (nitrogen and phosphorous in particular) has drastically increased input costs for producers over the past half century. In addition to soaring costs, the negative impacts on human and environmental health associated with widespread use (and overuse) of chemical fertilizers are numerous. Runoff and volatilization of nitrogen and phosphorous continues to adversely affect human health. Ecosystems exposed to excessive nitrogen and phosphorous inputs may increase the prevalence of parasitic and infectious diseases (e.g., malaria, West Nile virus, cholera, and schistosomiasis) [9,10]; depending on the response of host species to environmental stresses [11]. Additionally, tropospheric ozone from nitric oxide and ammonia emissions are known to exacerbate pulmonary disease, and potable water polluted with nitrate has the potential to increase cancer and reproductive risks [9]. Taken together, the effects of nitrogen oxides on human health and ecosystems is estimated to represent $75 \%$ of the total damage costs associated with excessive reactive nitrogen in the environment [4].

Excessive nitrogen can wreak havoc on natural ecosystems. Evolution of the many molecular forms of nitrogen (nitrate, nitrite, nitric oxide, and nitrous oxide) through the environment allow nitrogen ions to contribute to more than one of several detrimental environmental impacts; including loss of biodiversity, eutrophication of coastal rivers and bays (affecting approximately 67\% of coastal 
ecosystems in the United States of America) [12], ground water pollution, soil acidification, and greenhouse gas emissions $[9,13]$. These negative environmental impacts now cost the European Union twice as much as the value that nitrogen fertilizers add to farm incomes [14].

Active nitrogen from agricultural lands is projected to deposit approximately $10 \mathrm{~kg} \mathrm{~N} \mathrm{ha}^{-1} \mathrm{yr}^{-1}$ into the environment by 2050; a rate twenty times that of natural deposition [9]. These elevated levels will (and already do) contribute to increased greenhouse gas emissions (e.g., nitrous oxide, methane, and carbon dioxide) [15]. Of particular concern is the release of methane and nitrous oxide from agricultural lands [8]. Approximately 50\% of anthropogenic methane [16] and 70\% of anthropogenic nitrous oxide emissions (resulting mainly from the overuse of nitrogen fertilizers) are now attributed to agriculture production [5]. Methane production in arable soils results from the breakdown of organic compounds by microorganisms under anaerobic conditions and at low redox potentials [8]. The most common source of nitrous oxide production from cultivated lands is through microbial denitrification under anaerobic conditions and at high redox potentials [17]. Between the 18th and the 20th centuries atmospheric nitrous oxide concentrations have increased from $270 \mathrm{ppb}$ to $314 \mathrm{ppb}$ [18]. Nitrous oxide possesses a global warming potential 296 times greater than carbon dioxide and 13 times greater than methane [19]; and is currently responsible for approximately $6 \%$ of the global warming attributed to greenhouse gas emissions [20].

The deterioration of natural ecosystems (e.g., eutrophication of coastal environments and greenhouse gas emissions), depletion of resources (e.g., water withdraw in excess of natural recharge), increasingly limited and expensive inputs (e.g., fertilizers and pesticides), and adverse impacts on human health require new, innovative approaches to agricultural management in order to meet the demands of a rapidly growing global population. These approaches should strive for the sustainable intensification of production through the maximization of agricultural yields and minimization of negative impacts. Twenty-first century management practices must balance agricultural production needs and ecosystem goods and services (e.g., potable water, biodiversity, carbon storage, pest control, pollination, fisheries, and recreation) [7,13,21]. Successful sustainable production systems will actualize appreciable yields regardless of the presence biotic and abiotic shocks; requiring such systems to be based on local values and constraints and, therefore, region and culture specific [3,22].

\subsection{Attaining Sustainability}

New super varieties (i.e., "miracle" varieties) of maize, wheat, and rice have allowed for increased yields through higher harvest indexes, lodging resistance (e.g., shorter stature and increased stalk strength), and greater resistance to biotic and abiotic stress [7]. Combined with high inputs of chemical nitrogen and phosphorous fertilizers, producers have been able to continuously increase crop densities; enhanced land productivity that currently supports approximately half of world population [4]. However, attainable yield potentials (estimated to be approximately 70\%) have, for the most part, already been realized in much of the industrialized world for current super varieties [3]. Yield potentials are commonly limited by water stress (i.e., droughts, flooding, and root and vascular diseases) and poor soil structure and fertility; constraints that cannot simply be overcome through improved varieties and increased fertilizer inputs [7]. 
Low agricultural water-use efficiencies are of increasing concern to both producers and consumers. Globally, human water consumption now represents $23 \%$ of the renewable fresh water supply [23]; with a majority consumed by agriculture (outpacing both municipal and industrial uses) [24,25]. By 2025 human water consumption is expected to more than double to approximately $70 \%$ of accessible runoff [6]; with some regions consuming significantly more (e.g., 94\% of annual water consumption in Iran is used for agriculture) [26].

Efforts to better manage water usage in agriculture is complicated by the fact that many of the services provided by natural aquatic ecosystems that are of importance to urban populations have little or no value to agriculture producers [3], creating tension through a conflict of interest. With world urban populations expected to double by 2025 [6], increased competition for water resources between agriculture, cities (e.g., potable water and electricity generation) [27], fisheries, and recreation is sure to emerge [3]. This situation is compounded by the fact that less than $1 \%$ of all fresh water on Earth is accessible for human consumption [23] (fresh water represents $2.5 \%$ of all water on Earth) and, furthermore, it is not evenly distributed among arable land and population centers (e.g., approximately 2 billion people live in water-stressed areas) [28].

In addition to growing concerns over water resource stresses, large-scale irrigation has also begun to attract scrutiny for its potential negative impact on human health. Representing $95 \%$ of irrigation systems worldwide [29,30], flood irrigation frequently relies on water retention basins as a primary means of storing water. These open reservoirs provide a breeding media for insect vectors of several tropical diseases. Increases in the concentration and proximity of humans to irrigated cultivation raise the frequency of infectious disease outbreaks [31]. Diseases of concern include but are not limited to: malaria (1 million deaths annually), schistosomiasis (200 million infections annually), and lymphatic filariasis (120 million infections annually with 1.1 billion at risk) [30,32-34].

Decreasing (or limited) fresh water supplies and environmental concerns have, over the course of the past 30 years, slowed investments in irrigation (5\% decrease per capita) [7]. Furthermore, new dam construction is estimated to only increase by $10 \%$ during the next three decades [3]. Given the fact that some estimates indicate $60 \%$ of future food demands will depend on some form of irrigation, this declining investment in irrigation systems is concerning [35]. Low water-use efficiencies and negative impacts on human and environmental health mean that improved water management in agriculture represents a great opportunity (e.g., through the development and integration of precision, micro-irrigation systems) to reduce pressure on fresh water resources and improve both environmental and human health.

Beyond increased investments in irrigation systems and development of stress resistant super varieties, large applications of nitrogen and phosphorous fertilizers have also contributed to increased yields during the past half century. In fact, between $30 \%$ and $50 \%$ of yield increases associated with the Green Revolution have been attributed to increases in chemical nitrogen applications [36]. Accordingly, access to affordable chemical nitrogen fertilizer has become an increasingly critical component of production agriculture; generated via the Haber-Bosch nitrogen fixation process (out of the $187 \mathrm{Tg}$ of reactive nitrogen produced in 2005, $100 \mathrm{Tg}$ was created through the Haber-Bosch process) [9]. Approximately $80 \%$ of total reactive nitrogen is currently consumed by agriculture; with $48 \%$ of the world population now dependent on crops fertilized with chemical nitrogen [36]. 
Over the past four decades growing dependence of agriculture on chemical fertilizers has resulted in a massive increase in the global application of nitrogen and phosphorous [31,37] that will at least double by 2050 [13]. As a consequence, humans now rival natural ecosystem processes for nitrogen and phosphorous deposition into the environment [13] by applying half of all nitrogen fertilizer ever used during the last two decades of the 20th century [10]. Increased demand, reduced input use-efficiencies (e.g., nitrogen use-efficiency decreased from 80\% in 1960 to 30\% in 2000) [36], and rising energy costs, have more than quintupled the costs of chemical nitrogen and phosphorous fertilizers [37]; input costs that now exceed land preparation costs and are the highest direct agriculture production expense [5]. In fact, between $50 \%$ and $70 \%$ of applied nitrogen and 35\% of applied phosphorous is not taken up by crops [13]. These inefficiencies alone are estimated to cost European Union producers between $\$ 16$ billion and $\$ 85$ billion in lost potential benefits [4].

\section{A Brief History of Agriculture Intensification}

\subsection{The Emergence of Agriculture as a Science}

Scientific and technological innovations have fundamentally shaped the history of agriculture and, consequently, the history of human civilization; with the continual development and refinement of tools and methodologies for agricultural production fueling at least five distinct agricultural revolutions. These include: the Neolithic revolution beginning around $9000 \mathrm{BC}$, the ancient revolution beginning around $3500 \mathrm{BC}$, the medieval revolution beginning around $500 \mathrm{AD}$, the contemporary revolution of the eighteenth century, and Green Revolution of the mid-twentieth century [38]. Emergence of agricultural production as a science is frequently credited to notable scientists and agriculture researches such as Jethro Tull, Justus von Liebig, and Luther Burbank. The experiments conducted and programs developed by these men consequently led to the development of modern agriculture production management practices and, ultimately, the Green Revolution that relied heavily on mechanization, large agrochemical inputs, irrigation, and high yielding crop cultivars.

Luther Burbank oversaw an intensive breeding program during the late nineteenth and early twentieth centuries, developing new varieties of fruits, flowers, grains, grasses, and vegetables; creating and utilizing novel grafting, hybridization, and cross-breeding techniques [39]. Through his development of the seed drill and refinements to plough design [40] Jethro Tull greatly contributed to the foundations of modern production agriculture by promoting what, in modern terms, could be described as a sustainable soil management system (reviewed in [41]).

Justus von Liebig's research during the mid-19th century laid the foundation for modern inorganic and organic chemistry [42]; emphasizing that systematic practical experience was a necessary component of scientific study [43]. He is credited with developing the idea that minerals (e.g., nitrogen, phosphorous, and potassium) are required for plant growth [44]; a realization that lead to his Law of the Minimum which contends that plant growth is restricted by the least available nutrient when all other nutrients are in excess (i.e., adding nutrients other than the requisite nutrient will not result in additional growth) [45]. Justus von Liebig's advancements helped lead to the creation and utilization of fertilizers, an intrinsic component of the future Green Revolution [42]. 


\subsection{The Agricultural Green Revolution}

Beginning in the mid-1960s and continuing through to today, the Green Revolution has approximately doubled agricultural yields through intensification of crop production [7,46]. This two-fold increase in yields has been realized through the development of super varieties of maize, wheat, rice and other crops, the large-scale integration of mechanized equipment, the adoption of modern irrigation systems [47], and massive increases in the application of chemical fertilizers and pesticides [5]. Through the integration of these modern production management technologies, land area under cultivation has grown by less than 20\% [13], facilitating intensification without necessitating the conversion of all available arable land and, therefore, helping to preserve many ecosystems that would have otherwise been converted for agriculture production [48].

Despite the agricultural advances of the past half century, 6 billion people currently live in poverty, 2 billion lack a diet containing sufficient iron, iodine, and vitamin A, and 840 million are undernourished [36,38]; a situation that is forecast to worsen in the coming decades. World population is projected to increase $50 \%$ by 2050 [49]; with a corresponding 2.4-fold increase in per capita real income [3]. This increased population, with its growing spending power, is expected to more than double world demand for agricultural products (e.g., food, fuel, and textiles) [38,50]; requiring greater yields per unit available land. Additionally, if recent historical trends are to continue (e.g., 60\% per capita meat production growth over the past 40 years) [37], increasing demand for animal protein will necessitate dramatic increases in grain production for fodder. This large usage of grain for meat production (e.g., $1 \mathrm{~kg}$ of animal protein requires between 3 and $10 \mathrm{~kg}$ of grain) [3] is highlighted in the European Union, where $85 \%$ of crop nitrogen is currently consumed by livestock [4]; representing $70 \%$ of cultivated crops [13]. Meeting world food and feed demands in the ensuing decades without further ecosystem degradation (i.e., as a result of high energy inputs, water resource depletion and contamination, and greenhouse gas emissions), and large increases in cultivated land area will require development of technologically innovative and resource-use efficient agricultural systems that will have similar impacts on society as the Green Revolution [25].

A contributing factor to intensive agricultural production is modern irrigation. Field irrigation systems are designed around several criteria; including start-up costs, field characteristics (e.g., shape, size, and soil type), available water resources, local climate, and crop varieties [29]. Integration of these systems (e.g., flood, sprinkler, and drip) into agriculture management schemes during the Green Revolution represented a substantial investment in infrastructure by producers; with cultivated land under irrigation increasing from 94 million hectares in 1950 to 276 million hectares in 2002 [51]. Increases in supplemental water inputs provided by irrigation have increased yield potentials, fertilizer responsiveness, and, along with greater chemical fertilizer inputs, facilitated substantial increases in cropping densities [7]; allowing the $16 \%$ of cultivated land currently under irrigation to produce approximately $40 \%$ of agricultural crops worldwide [3]. When properly utilized (e.g., appropriate system design and timely maintenance), modern irrigation systems allow producers to increase yield per unit of water through increases in water-use efficiencies and the minimization of water related crop stresses (e.g., insufficient rainfall for the realization of optimal yields) [29,30]; benefits that are used to rationalize increases in investment and production costs [47]. Despite these advantages, modern 
irrigation systems (e.g., flood and overhead sprinklers) are highly inefficient; wasting between 20\% and $50 \%$ of applied water [23].

\subsection{Traditional Approaches to Agriculture Management}

Over the past half century modern industry has successfully incorporated advanced technologies (e.g., automation through the utilization of modern robotic and sensor systems) into production strategies; a synthesis that has yet to be fully realized in agricultural production [15]. In fact, research spending dedicated to developing new, technologically driven agricultural production represents less than $2 \%$ of global agricultural GDP [52]. Efficacious 21 st century farm management solutions must employ precision input management schemes through the incorporation of existing, innovative science and engineering technologies. These successful systems will integrate real-time field level data collection, intelligent decision-making, and task automation [15] to reduce inputs and improve (or maintain) ecosystem health [5].

Approaches to agriculture management can be broadly grouped into three distinct categories; all of which involve making the growing environment and resource inputs more favorable for crops [53]. These three management groups include: macro-level management, meso-level management, and micro-level management [54]. The intensive management systems developed and adopted during the Green Revolution commonly employ a macro-level, large-scale mono-crop production approach that utilizes field-level, uniform input applications of fertilizers, pesticides, and water resources. These systems have been integral in the effort to meet ever-increasing agricultural demands during the past half century. However, this approach to production management has led to large inefficiencies in resource uses and escalating production costs. The benefits associated with this management approach (e.g., yield increases through intensification) have, unfortunately, been counterbalanced by negative impacts on socioeconomic and ecosystem health [13].

Meso-level agricultural management schema exploit soil parameter data (e.g., moisture, temperature, acidity, and nutrient concentrations) to variably apply inputs (i.e., fertilizers, pesticides, and water) across a field [55]. This intra-field approach to soil management employs modern, commercially available sensors to collect soil parameter data (e.g., soil macro- and micronutrient pools, acidity, moisture, and structure). Data collection includes laboratory-based, inductively coupled plasma analysis for soil fertility testing (mostly $\mathrm{P}, \mathrm{K}, \mathrm{Ca}, \mathrm{Mg}, \mathrm{Zn}, \mathrm{Mn}, \mathrm{Cu}, \mathrm{Fe}$ and $\mathrm{B}$ content) (e.g., http://www.soiltest.vt.edu/) [56], land and aerospace-based VIS/NIR (visible and near-infrared) spectrography (e.g., to estimate soil moisture content, crop canopy cover, and surface water resource levels) (e.g., http://www.veristech.com) [57], and vehicle mounted and handheld induction- and resistance-based soil sensors (e.g., electrical conductivity to estimate soil water holding capacity, organic matter content, and cation exchange capacity) (e.g., www.LSUAGCenter.com [58] and http://www.geonics.com [59]). Soil data are typically collected once or twice per year with expensive, tractor-mounted sensors and are coupled with GPS (global positioning system) location data to create digital spatial and temporal maps representative of parameter variation across the field. Once created, these maps allow for the variable rate application of water, chemical fertilizers, and pesticides. If the data are collected infrequently the application of soil amendments will likely be inadequate. As with 
macro-management, this meso-level management approach to agricultural production relies heavily on agricultural inputs to increase (or simply maintain) the fertility of top soil.

Micro-level agricultural management approaches are beginning to emerge as an advanced alternative to traditional macro- and meso-level management [41]. This novel methodology should allow for the management of agriculture production on an individual plant basis [60] through subsurface inputs delivery and the utilization of multiple inexpensive soil-sensor nodes (motes) positioned throughout the field to provide real-time soil parameter data. Sensor nodes can provide data related to soil respiration (e.g., soil oxygen and carbon dioxide levels), moisture, temperature, and acidity. These data can be collected and stored locally (e.g., data logger) or transmitted in real-time via wireless (e.g., Bluetooth) communication to a computer, and then to a portable handheld device (e.g., iPhone). The data, coupled with subsurface input delivery (e.g., www.kisss.com.au [61] and www.irrigro.com [62]) of water, gas (air, hydrogen, or gas mixtures), low doses of soluble fertilizers (organic and/or inorganic), and plant protection chemicals as required, will allow farmers to minimize production costs while actively manipulating microbial communities in soil, nourishing plants, and affecting soil structure and plant and soil health. In an effort to realize management on a small planting area, or an individual plant basis (e.g., in orchards, vineyards), a "smart field" at the Virginia Tech Catawba Sustainability Center in Catawba, Virginia has been developed (J. Gabbard, J. Weekley and J. Nowak, unpublished [63]). The smart field has been suggested as a technology platform to study the beneficial effects of micro-level precision soil management in agricultural production [41]. The Catawba Sustainability Center smart field utilizes unique sensor and communication systems to acquire, transmit, and provide researchers and managers access to real-time data related to plant physiology, soil environment, and atmospheric data. The smart field evolved out of the laboratory and now represents a versatile technological platform for exploring unique, 21 st century approaches to maximizing yields while minimizing negative social and environmental harms through the sustainable intensification of agricultural production.

\section{Modern Approaches to Agriculture Management-Utilization of Plant Growth Promoting Microorganisms (PGPMs)}

Millions of years of coevolution of terrestrial plants and soil microorganisms have resulted in plant-microorganism relationships that support an incalculable number of functional interactions [64]. The specificity of these relationships is such that the number and composition of host microbial consortia fluctuate not only between species and cultivar [60], but also among plant tissues [65] and throughout plant developmental events [66]; often taking advantage of specific niche utilization [60]. Though microorganisms are commonly described only in terms of pathogenic potential, plant-microbial associations can, in fact, be characterized as beneficial, neutral or pathogenic; with each association representing approximately 33\% of all observable interactions [60]. Mutualistic plant-microbe relationships occur on two levels: endophytic and rhizospheric [67]. Endophytic microorganisms are described by Wilson et al. [68] as "fungi or bacteria, which for all or part of their life cycle, invade the tissues of living plants and cause unapparent and asymptomatic infections entirely within plant tissues." Plant tissues and organs colonized by endophytic bacteria and/or fungi include xylem tissues [69,70], seeds, roots, stems, leaves [71], fruits and flowers [72], and tuber 
tissues [60,67]. The acute interdependence of plant host and microorganisms form mutualistic associations that developed through evolutionary mechanisms and resulted in the number and genetic information of microbial consortia typically exceeding that of the host plant [73]. Taken together, this genetic information is known as the hologenome [73]. The combined host-microbial consortia unit (i.e., holobiont) is better equipped for evolutionary survival and fitness through the ability of microbial consortia to more rapidly fluctuate; increasing genetic variability and leading to higher evolutionary rates (i.e. the ability to adapt to changing environmental conditions) [73,74]. Documented benefits of plant-microbe symbiosis include greater growth rates (shoots and roots) $[71,75,76]$ and host's overall surface area [77], greater proliferation of root hairs (i.e., root branching and improved root-soil contact for greater nutrient and water uptake) [78,79] and increased resistance to biotic and abiotic stresses [65,76] (e.g., transplantation, drought, and heat) [80-82]. Larger bacterial communities predominately result in greater plant growth promotion $[65,83]$. However, growth promotion benefits may not become apparent until the onset of stress [84]; which, after onset, may gradually encourage the improvement and strengthening of symbiotic relationships during crop growth [60].

Soil microorganisms are an integral component of the soil solution (affecting soil health both positively and negatively) [22] and bulk soil is the main source of plant-associated symbiotic microbial consortia [60,85]; with anthosphere, carposphere, leaf stomata, and above ground wounding sites acting as additional microbial entry points $[72,86]$. Soil microorganisms translocate from bulk soil to rhizosphere (i.e., the soil volume influenced by rhizodeposits) [86] to rhizoplane to endorhiza and then throughout internal plant tissues [60,71,72]; frequently establishing non-uniformly [87]. To attract and encourage the establishment of microbial consortia, plants may release up to $50 \%$ of their fixed carbon into the rhizosphere $[88,89]$. Another source of rhizosphere carbon deposition is root cells shed by plant root systems (either through root growth or death). These sloughed root cells attract, support and maintain specific rhizosphere microbial consortia [90]. Plant roots also excrete water (especially during periods of darkness) that facilitates bacterial motility and translocation [91]. In fact, dense root tip bacterial communities have the potential to greatly influence plant available nutrients [92].

Rhizodeposition by plants, combined with root turnover, is a major driver of soil microbiological processes; accounting for up to $40 \%$ of carbon input into soil $[93,94]$. Plant exudates include organic compounds (e.g., organic acids form the nutritional basis of rhizosphere colonization) [95], inorganic ions, allelochemicals [96], phytotoxins, phytoalexins, phytohormones and ectoenzymes [90]. These exudates vary between plant species, cultivar, growth stage, and host's health [97,98] and are known to elicit different microbial gene responses [86]. In addition to chemical signals, plants may also rely on electrogenic ion transport generated electric potentials to attract microorganisms [99]. These rhizosphere investments by plants vary, depending on ecosystem type, plant species, and host's growth stage [90].

Plant-microbial associations are quid pro quo relationships; with bacteria also producing and excreting many organic and inorganic volatile compounds and siderophores that benefit the host plant $[84,95,100]$. Microbial exudates may contribute to plant growth and health through enhanced nutrient availability (e.g., nitrogen fixation, phosphorous mobilization, and iron sequestering siderophore production) [94] and/or by acting as antagonistic agents against root pathogens (e.g., lytic enzyme production and detoxification and degradation of virulence factors) [101,102]. Siderophore sequestration helps to deprive pathogenic microorganisms of nutrition (i.e., iron) and its production is 
affected by soil acidity and ion concentrations [102]. Additional plant growth promotion mechanisms attributed to beneficial soil microorganisms are microsite competition [103] and secretion of phytohormones $[65,104]$. The relationship between plant host and endophytic microorganisms is not passive. Endophytic bacteria and fungi communicate through signaling molecules (e.g., quorum sensing) [105] that plants are able to recognize [106]; molecules that, combined with plant and microbial exudates, influence and modify root structures and exoroot bacterial communities [60,64,74]. In general, root growth leads to increased substrate loading that promotes microbial growth which in turn promotes additional root growth [41].

Colonization of plants by soil microorganisms follows several phases, such as: gene-based recognition and chemotaxis [107], adherence (involving an initial weak and reversible attachment followed by a second strong and permanent attachment), invasion (for endophytes and pathogens), colonization and growth [90,108]; with belowground plant tissues and surfaces (rhizosphere, rhizoplane and endorhiza) experiencing greater bacterial population concentrations than above ground tissues and surfaces [60]. Several environmental soil conditions influence both the establishment of microbial consortia and population densities of specific soil microorganisms within the consortia [60]. These include acidity [109,110], moisture content and water availability [111], temperature, partial pressure of oxygen [112], salinity, redox potential, soil type [113] and above ground vegetation $[114,115]$. Other critical factors influencing the establishment and diversity of microbial consortia are host genotype and local mycorrhizal structures causing axillary branching of roots [64]. Successful rhizosphere colonization by soil microorganisms is also dependent on efficient substrate acquisition, resistance mechanisms to biotic and abiotic stresses, and competitive traits [90]. Bacterial micro-colonies can grow from the attachment of a single cell $[95,116]$. Following initial establishment on the root, the plant-bacterium alliance may attract and/or stimulate growth of other plant growth-promoting microorganisms [67]; frequently colonizing on exudation sites [116]. Once established, bacterial consortia can be passed from dead or dying roots to newly emerging and/or already developed roots (bacterial consortia continuity throughout the life of the plant); with different root types typically colonized by different bacteria and fungi species [92].

Though plant roots are the largest fraction of biological material in most arable soils [72], the plant rhizosphere is only a small fraction of the total soil volume [115]. The rhizosphere is a complex and dynamic zone where plant roots, soil microorganisms and adjacent soil conditions interact $[90,95,117]$. Properties of soil in the rhizosphere are influenced by the presence and activity of the plant root and include changes in the physical, chemical and biological parameters affecting plant growth and health [90,94]. These capabilities are limited to the rhizosphere; with plants exerting little or no influence in bulk soil [115]. Due to the active interaction between plant roots and soil-borne microorganisms, management of the rhizosphere zone of crop plants is considered a strategic target in the development of environmentally friendly and sustainable agricultural production [118].

Despite a historical knowledge in the scientific community of the existence of symbiotic plant-microbial associations, only recently have scientists begun to study in depth mechanisms of the benefits of these relationships [41]. A major challenge in this delayed investigation is the reality that up to $80 \%$ of soil bacteria have yet to be characterized [119] making it difficult to determine microbial species critical to plant productivity [120]. Although plant growth-promoting microorganisms (PGPM) are a promising alternative to high input management practices developed during the agricultural 
Green Revolution [95], the twentieth century breeding program objectives did not include beneficial plant-microbial associations. Plant growth-promoting microorganisms have been shown to enhance host plant root system, improve its water management capability, pathogen resistance, and increase phenolic and chlorophyll content of plant tissues [76,78]. These relationships could be exploited in agricultural biotechnology [118] as a sustainable avenue for maximizing crop growth to close present day yield gaps $[41,121]$.

Commonly known plant growth-promoting microorganisms are bacterial or fungal in nature. Bacterial species of interest primarily include Pseudomonas, Bacillus, Burkholderia, Rhizobium and Azospirillum [85,118,122-124]. Fungal species include Ampelomyces, Coniothyrium [118] and Trichoderma [125]. Bacteria may be more promising for the establishment of long-lasting beneficial associations $[60,126]$; with bacterial species tending to colonize a larger number of plant species (i.e., greater overlap among plant species and cultivars) [90] than fungi [108]. In addition to increased nutrient and water availability and greater resistance to pathogens [102], microbial growth promotion mechanisms also involve the mediation of soil processes (i.e., decomposition, nutrient mobilization, and mineralization) [22]. The root protective florae that provide benefit to plants cannot only colonize the rhizosphere and rhizoplane but also the root interior (endorhiza) [60], affecting bacterial community phenotype and functionality through signaling molecules and excretions. These altered local soil environmental conditions then affect plant root function, disease suppression, and physiological development (e.g., observable root growth stimulation in cucumber, pepper, potato, tomato, and watermelon) $[65,78,80,83,127]$.

A majority of surveyed plant species and families have been found to host arbuscular mycorrhizal (AM) fungi [90,128]. These fungi alter plant physiology through their influences on the mineral compositions of plant tissues, plant hormonal balances and carbon partitioning [97]. Establishment of arbuscular mycorrhizal fungi in roots is known to enhance plant biomass, increase nitrogen and phosphorous tissue content [67], improve uptake of micronutrients (e.g., $\mathrm{Ca}, \mathrm{Cu}, \mathrm{K}, \mathrm{Mg}$ and $\mathrm{Zn}$ ), protect against biotic and abiotic stress (which are responsible for up to $50 \%$ of crop losses worldwide) [129] and improve soil structure [94,130,131]. Arbuscular mycorrhizal fungi may increase plant water and nutrient availability through elevated vascular osmotic pressures (e.g., improved plant transplantation survival) [132] (reviewed in [60,133]) and increase its access to water in soil pores that are of insufficient size for root extraction (soil pores that are smaller than $0.2-0.3 \mu \mathrm{m}$ in diameter) [92]. These fungi explore bulk soil with external hyphae [22] that may act as an evolutionary alternative to the production of cluster roots by plants [94,134]; extending plant access to soil water and nutrients from just a few millimeters to several centimeters [94,135]. Increases in plant-available phosphorous are also attributed to phosphorous solubilization and changes in microbial consortia that result from arbuscular mycorrhizal colonization and its associated mycorrhizosphere [136]; which supports microbial relationships similar to those found in the plant rhizosphere [94]. In fact, arbuscular mycorrhizal fungi form tripartite associations with bacteria consortia and host plants [137]. Within the mycorrhizosphere species are able to influence bacterial communities through exudates encouraging growth of mycorrhizal helper bacteria [138]. These bacteria can then stimulate mycelial growth and enhance mycorrhizal colonization of plant roots [94,139] through increases in root cell permeability, root exudation rates, and/or production of phytohormones $[94,136]$. 
One of the major soil inhabitants, protozoa, also significantly influences soil microbial communities. Protozoan biomass is substantial; equaling or exceeding all other soil animal groups combined and exerting greater influence on plant biomass and nutrient turnover than earthworms [88,94]. Protozoa consume (i.e., selectively graze) bacteria in the rhizosphere, releasing nutrients and helping to regulate and control plant-growth promoting microbial communities through the promotion of diverse populations [88]. Protozoa grazing has been shown to increase shoot biomass and nitrogen concentrations through nitrogen mineralization [88] even in the absence of enhanced nutrient supply (e.g., fertilizer application) $[140,141]$.

Nitrogen and phosphorous are growth limiting plant nutrients; often greatly affecting crop yields [67,142]. The ever-increasing costs associated with application of fertilizers is now driving research into the utilization of biofertilizers (i.e., the use of soil microorganisms) to increase nutrient availability and uptake in the commercial production of crops (i.e., nitrogen, phosphorous, and other macro- and micro-nutrients) [67,143]. Biological fertilizer can be any microorganism-containing substance applied to seeds, soil, or plant surfaces that help to establish colonies of beneficial microbial consortia in the rhizosphere, rhizoplane or endorhiza [67]. Biological fertilization includes the replacement of soil nutrients, solubilization of plant-unavailable forms of nutrients, and siderophore production that aid transport of nutrients from soil solution to plants [67]. Challenges associated with biofertilization include inoculant survival, microorganism's compatibility with targeted host plants, and determination of adequate environmental conditions for the establishment of symbiotic relationships [22]. These challenges foster fundamental research likely leading to the use of biologicals in agriculture [67].

Soil microorganisms are an integral part of the soil nitrogen cycle involving fixation, nitrification, denitrification, and mineralization [144,145]. Soil nitrogen availability is a function of soil ion concentrations and water content, root distribution, and plant growth rate [94]. Nitrogen uptake by plants as ammonium and nitrate is influenced by root length and branching, physiological response mechanisms, and the interaction of host plants with associated exo- and endophytic microbes. In the absence of chemical nitrogen fertilizer applications, crops can acquire nitrogen from biomass decomposition in soil and via nitrogen fixing microorganisms. Biological nitrogen fixing microorganisms are the main source of plant available nitrogen for most soil and water ecosystems [146]; with microbial nitrogen fixers providing up to $80 \%$ of nitrogen for some grasses [147], $90 \%$ for nodulating plants, primarily legumes [94,148], and 65\% for crops worldwide [95]. The best known examples of biological nitrogen fixation include symbiotic nitrogen fixing bacteria which nodulate leguminous crops. However, free-living nitrogen fixing microorganisms may also play an important role in producing plant-available nitrogen; with genera of known free-living nitrogen fixing rhizobacteria including Azospirillum, Herbaspirillum, Acetobacter and Azoarcus [95]. Despite the potential of free-living nitrogen fixers, endophytic nitrogen fixing microorganisms may prove to be beneficial to host plants beyond acquisition of nitrogen $[60,67,149,150]$. Adesymoyer and Kloepper [143] argue that phytohormone production by free-living diazotrophs may be their greatest contribution to plant growth and health through improved root growth, enhanced organic acid extrusion, and increased water and mineral uptake.

Symbiotic biological nitrogen fixers are commonly associated with leguminous crops, with over 15,000 species forming specific associations with root nodulating nitrogen fixing Rhizobia [73]. 
Rhizobia genera with the greatest potential include Rhizobium, Sinorhizobiumi, Mesorhizobium, Bradyrhizobium, Azorhizobium and Allorhizobium [95]. The new challenge for researchers and producers is the reduction of chemical nitrogen fertilizer inputs through the integration of biological nitrogen fixing microorganisms into non-leguminous crops [95].

Phosphorous promotes nitrogen fixation in leguminous crops and is essential for photosynthesis, and energy and sugar production [22,151]. Soil organic phosphorous, ranging between $30 \%$ and $65 \%$ of total soil phosphorous, must be converted to inorganic or low-molecular weight organic acids before plants are able to uptake it [143]. Both mineralization of soil organic phosphorous and phosphate solubilization from rock phosphates are the two natural processes aided by rhizosphere microorganisms that increase phosphorous availability to plants [22,67,94,152-154]. Organic acids derived from the microbial decomposition of biomass help to liberate phosphorous from both organic compounds (e.g., phytates) [155] and rock phosphates, establishing a phosphorous gradient between the rhizosphere and bulk soil [94,156]. Phosphate solubilizing microorganisms include bacteria and fungi [94] equipped with organic acid mobilization mechanisms that involve reduced sorption of phosphorous, desorption of orthophosphate, and chelation of cations [94,157]. Global production costs for phosphorous fertilizers are estimated to reach approximately $\$ 4$ billion per year [22,154]. Therefore, the ability to develop and exploit phosphate solubilizing soil microorganisms could lead to more efficient utilization of phosphorous soil reserves and external inputs [22].

Phytohormone production helps to prevent plant infections [158] and stimulates the establishment of beneficial plant-microbial associations [121] that can influence the hormonal balance and growth of plants $[94,95,118]$. These phytohormones include auxins (e.g., indole-3-acetic acid), cytokinins (both isoprenoid and aromatic) [159], gibberellins, ethylene, salicylic acid, abscisic acid, and jasmonic acid; with plant growth effects dependent on their relative concentrations [84]. Auxins are commonly produced by plant-growth promoting microorganisms [160]; with up to $80 \%$ of rhizosphere bacteria producing indole-3-acetic acid (IAA) [161] that can be used as a carbon source for growth [90,162] and as a catalyst of cell elongation, formation and organization of vascular tissues, root initiation, apical dominance, and fruit growth and development [163]. However, plant responses to indole-3-acetic acid vary among species and varieties and, therefore, its production may become a source of stress in localized host-environment combinations [164]. Cytokinins promote cell division, growth and differentiation, apical dominance, auxiliary bud growth, and leaf senescence [163]; and are also an integral component of local and long-range [159] root-to-shoot nitrogen availability communication [165]. Plant cytokinin production and concentrations vary among species, plant tissues, growth stage, and nitrogen availability [159]. Lazarovits and Nowak [78] demonstrated that plant-associated bacteria can induce synthesis of cytokinins in colonized potato plants in the early developmental stages and/or facilitate uptake of cytokinins from the environment. The presence of gibberellins in plant tissues is associated with stem elongation, germination, dormancy, flowering, sex expression, enzyme induction, and leaf and fruit senescence [163]. Ethylene (i.e., the "wounding hormone") production in plants influences fruit ripening [41], flower opening, leaf and fruit abscission [90], inhibition of root elongation [67], release from dormancy, shoot and root growth and differentiation, adventitious root formation, root system morphology, and plant responses to biotic and abiotic stresses [90] (e.g., heavy metals, ozone, pathogen attack, and flooding) [166]. Ethylene can also be produced by soil microorganisms [167]. 
Plant growth promoting microorganisms may also reduce the production of ethylene through the excretion of ACC deaminase that can cleave the precursor of ethylene, 1-aminocyclopropane-1carboxylate (ACC), to ammonia and $\alpha$-ketobutyrate $[166,168,169]$. The plant growth promoting effects of ACC deaminase may be most effective during pathogen attack [94,170-172] and in stressful environments (e.g., flooded and heavy-metal contaminated soils) [173,174]. Additionally, under stress conditions plant vitamin synthesis declines. Vitamin producing rhizobacteria may help to stimulate plant growth and yield under less than optimal growing conditions [94].

Similar to biofertilization, microorganisms could also be utilized as biological pest controllers (i.e., anti phyto-pathogenic); with "primed" plants better able to endure biotic and abiotic stresses after exposure to beneficial soil microorganisms [132]. Vessey et al. [67] define biological pest controllers (i.e., biopesticides) as "bacteria that promote plant growth through the control of deleterious organisms;" with reduced stress levels known to enhance crop yields [102]. These microorganisms help to increase resistance to pathogen attack through enhanced response to stress signals, protection (e.g., through strain competition) against soil-borne pathogens [96] or deleterious rhizobacteria [102,175] (e.g., exclusion of pathogens through the occupation of niche microsites) [176], nutrient competition [60,177], siderophore production [102,178] (i.e., increased uptake of nutrients by plant growth promoting microorganisms deprives pathogenic organisms of nutrition) [67], parasitism [118], and induced systemic response (ISR) [102,179,180]; with anti-pathogenic mechanisms dependent on plant genotype, growth stage, and local environmental conditions [105]. Microbial-mediated induced systemic response in plants may provide a broad spectrum resistance against multiple pathogens [41,132] and is influenced by plant physiology and biochemistry, as well as local environmental conditions [118]. Additionally, some bacteria (e.g., Pseudomonas spp.) and bacterial consortia [102] produce antibacterial and antifungal agents $[60,95,102,181]$ that may enhance resistance to pathogen attack in plants (e.g., pyrolueteorin, pyrrolnitrin, phenazines, hydrogen cyanide, and viscosinamide) [53]. Therefore, microbial biopesticides (possibly in combination with artificial substrate vibration disruption) [182] are a promising environmentally friendly and sustainable approach to field-level pest control for agricultural production.

Utilization of plant growth-promoting microorganisms (e.g., through biofertilization, biological pest control, or phytohormone production) can be realized either through the management of native soil microorganisms or through inoculation of crops with autochthonous microorganisms [118]; with their use representing an opportunity to engineer the rhizosphere through artificial symbiosis $[90,183,184]$. However, microbial inoculants should not inhibit the functionality of beneficial, autochthonous bacteria consortia [64] and should not show pathogenicity towards human tissues [86]. Biological nitrogen fixation inoculants have been commercially available since the 1890s [185]; with microbial inoculants (e.g., "BioGro") continuing to represent a growing commercial market (e.g., 10\% annual growth rate) [118]. "BioGro" is a commercially available biofertilizer containing four strains of bacteria selected from rice rhizospheres in the Hanoi area of Vietnam that can be applied to seedlings or directly to fields; it has been shown to increase plant growth and nutrient uptake $[186,187]$. Compared to agrochemical nutrient applications, advantages of microbial inoculants include improved safety, reduced negative environmental and human health impacts, greater functionality (e.g., improved nutrient uptake and pathogen protection in combination), and greater effectiveness in smaller quantities [118]. However, field-level (i.e., in situ) establishment of microbial inoculants 
(i.e., non-native/resident) is difficult [64]. This is a result of competition from indigenous microorganisms, poor rhizosphere competence, and difficulties associated with the culturing of potential inoculants [64,76]; with age and concentration of inoculants greatly influencing the efficacy and timespan of benefits [175]. Early establishment of beneficial inoculants may help the survival of non-indigenous consortia through the minimization of negative microbe-microbe interactions [64].

Inoculants are typically applied via seed amendments [22] or directly to seed-bed media [64]. Disadvantages of seed applications include limited adherence, influence of direct contact with seed applied chemicals and post-planting environmental stress, and the tendency of some microbial consortia inoculants to diffuse out of the rhizosphere [22]. Conversely, field-level inoculant applications (e.g., through a subsurface delivery system) benefit from the ability to apply greater microbial concentrations, lessened exposure to chemically treated seeds, lack of seed mixing, and benefits associated with establishment in a more natural soil environment [22]. Field-level inoculant delivery mechanisms could include incorporation into soilless mixes [188,189], nodal explants biotization [76], transmission through vegetative reproduction or biotization [60,73] (i.e., could reduce inoculation frequencies and associated costs) [65], and irrigation [175]. Successful, field-level inoculants must survive in the rhizosphere (i.e., colonize and thrive), efficiently utilize plant root exudates, and compete with indigenous microorganisms [95]. Furthermore, plants with slow growing root systems may prove more promising [92].

Potential microbial inoculants include both bacteria (e.g., Pseudomonads and cyanobacteria) and fungi, with combinations of multiple bacterial strains and/or bacterial and fungal strains improving inoculant survival and efficiencies [22,76,96,190,191]. These improvements through bacterial consortia or bacterial consortia in combination with fungal consortia may be a result of synergistic interaction between different microorganisms [94] (e.g., phosphate solubilizing microorganisms combined with biological nitrogen fixers) [22], indirect plant impacts through amendments to soil structures and solutions [74], and the redundant functionality of certain rhizospheric microbial consortia (e.g., "helper bacteria" and "insurance policy theory") [67,90,192]. Host's benefits include increased seedling root growth and weight, taller and sturdier stems (e.g., thicker stems with greater lignification), larger leaves, more ad ventitious and secondary roots, and greater top and root growth $[65,76]$.

\section{Micro-Level Agriculture Management: Opportunities and Challenges}

\subsection{Smart Field Technology Platform: An Introduction}

Goals and challenges of 21 st century sustainable agriculture include increased resource-use efficiencies, internal regulation of biological processes under agriculture production management, and the closing of nutrient cycles within agricultural production systems (i.e., outputs balanced with inputs) $[60,133,193]$; with appropriate and responsible soil management practices vitally important for the prevention of long term soil degradation [115]. These objectives must be met by balancing economic profitability, environmental health, and ethical soundness [142] through the development of novel and technologically advanced approaches to agriculture research and production [193]. A promising approach to sustainable intensification of agriculture production involves the utilization of 
endophytic and free-living bacteria and fungi; an avenue dependent upon the maintenance, manipulation, and modification of beneficial microbial consortia within specific cropping systems under field conditions [60]. Possible methods of manipulating plant endophytic microbial consortia include inoculation (i.e., seeds, micro-plantlets, and other vegetative propagules such as tubers, cuttings, and micro-grafts), encouragement and establishment of plant growth-promoting beneficial microbial communities (i.e., promote the presence and function of various bacteria and fungi consortia in different environments) [94], and/or gene for gene transfer of beneficial functionality from microorganisms into new crop varieties [60]. However, exploration of holistic (hologenomic) approaches to plant-microbial relationships through breeding and production for the establishment and maintenance of plant beneficial bacterial consortia may prove to be a more sustainable and socially acceptable approach to crop enhancement than genetic modification [41,95,132] (e.g., production of 1-aminocyclopropane-1-carboxylate deaminase by soil microorganisms is a more effective method for reducing plant ethylene levels than is the creation of transgenic plants) [166]. Plant and microbial rhizospheric exudates are poorly understood under field conditions; representing a potentially critical area of research and experimentation into understanding the mechanisms involved with spatial and temporal influences of specific plant-microbial consortia colonization and their effects on root system growth and dynamics (e.g., plant-microbial exchange of nutrients and chemical signals) [92].

Successful approaches to precision soil management for sustainable agriculture research leading to the refinement of production systems (e.g., sustainable intensification) will utilize smart fields that combine affordable, commercially available environmental sensors, digital imaging and data analysis, subsurface precision soil and plant-input delivery, and ground- and aerial-based autonomous vehicle technologies. Development of these systems will require collaborative, interdisciplinary teams comprised of soil and crop scientists, agronomists, foresters, microbial ecologists, and engineers [193]. Smart field technology platforms will be based on soil and plant biology and will target precision delivery of inputs synchronized with growth stages of crop plants. Technologically novel research and production systems may utilize multiple inexpensive, stationary solar powered soil sensor nodes (i.e., motes) positioned strategically throughout a field to provide real-time data related to soil, plant, and microbial growth and health. Environmental sensors can provide data related to soil respiration (e.g., soil oxygen and carbon dioxide levels), soil greenhouse gas emissions (e.g., methane and nitrous oxide), plant stress level (e.g., ethylene emissions), moisture, temperature, electrical conductivity (e.g., to monitor methane and nitrous oxide emissions) [17], and acidity. Fixed node sensor data could be combined with data collected by ground- and aerial-based autonomous vehicle mounted sensor systems and stored locally (e.g., data logger) or transmitted in real-time via wireless (e.g., Bluetooth) communication to a computer, or a portable handheld device (e.g., iPhone) for viewing, data mining (e.g., real-time and long-term trend data), and computer-based decision making to achieve automated, real-time best management practices (e.g., timely production interventions) [41].

Replacing flood irrigation with sub-irrigation and/or surface drip irrigation is a high priority in sustainable agriculture production [193]. Subsurface textile irrigation systems, such as the KISSS Below Flow Flat [BFF] (see www.kisss.com.au [61]), combine reinforced tubing, pressure compensating emitters, anti-percolation layers (i.e., discourage downward water movement), dispersion layers (i.e., minimize surface tunneling), and geo-textiles (i.e., encourage uniform capillary water movement) to provide many benefits beyond traditional flood and/or overhead sprinkler 
irrigation systems [194]. Advantages of subsurface water delivery include water-use reductions of up to $60 \%$ (e.g., minimizing evaporation, runoff, and tunneling during conveyance and delivery) [193], precision root zone water delivery, uniform water application, root intrusion deterrence without chemical inputs, and weed growth suppression [195]. Combined, these benefits encourage stronger plant roots, enhance plant growth uniformity, reduce water logging (i.e., minimize anaerobic soil events), and decrease soil salinity levels [194].

In addition to irrigation, subsurface precision delivery systems in combination with fixed and vehicle-mounted mobile sensor suites will allow managers and researchers to actively manipulate microbial communities in soil, and/or plant growth media, that affect soil health and structure through the real time delivery of supplementary inputs such as gas (air, hydrogen, or other gases/gas mixtures), soluble fertilizers (organic and/or inorganic) and plant protection chemicals in time [102] (i.e., input delivery synchronized with plant growth stage) [142] and space as required. Precision delivery of air (e.g., through the utilization of aerated water, see www.mazzei.net [196]) [197] would help to mitigate/prevent water saturated, anaerobic soil conditions (e.g., reduce anaerobic microsites) that increase plant stress and greenhouse gas emissions [8]. This preferential feeding of plants, soil, and plant-beneficial microorganisms, and precision input-based intervention for the timely alleviation of abiotic stresses will help to create both beneficial rhizospheres and healthy plant stands [41].

\subsection{Smart Field Technology Platform: Applications}

Investigations into plant inoculation with beneficial microorganisms in laboratories and/or greenhouses are insufficient for field-level research due, in part, to the physical, chemical and biological differences between laboratory/greenhouse and field soil conditions (i.e., different diffusion rates for plant and microbial exudation and chemical signaling in each growth medium environment) [92]. Presently, there is a dearth of referenced literature on the quality of commercial, non-rhizobial, inoculants; with more research into the long term viability of field-level inoculant strains and their associated effects on plant growth desperately needed [198] (e.g., quantification of biofertilizer and biocontrol agent efficacy) [86]. The proposed smart field platform would allow for the field-level study of plant-microbe associations observed in laboratory environments through scale-up trials and bioprocess development [118]; helping to build up native plant beneficial microbial consortia already adapted to particular soils and edaphic conditions, and/or determine optimal conditions for introduced inoculants to provide prolonged benefit to crops $[22,41]$.

The initial goals of the smart field investigations could focus on establishing beneficial plant associated microbial consortia through the utilization of soil priming techniques (e.g., to set the readiness of soil to receive specific growth-promoting crop-associated microorganisms); helping to improve beneficial microbial growth, increase humification of soil organic matter, and improve soil mineral and water holding capacities [41]. Other research opportunities may include the identification of genetic determinants for plant-microbial compatibility [86], analysis of microorganism ecology [41,94], the study of specific mechanisms (e.g., niche utilization) involved with the establishment of field-level microbial (e.g., native and non-native) inoculated crops (e.g., facilitation of on-site rhizospheric research to validate laboratory model studies and development of improved inoculants) $[86,90]$, and the possible development of real-time carbon sequestration quantification 
methods (e.g., through a better understanding of ecosystem carbon pools) to facilitate carbon credit trading (i.e., additional income) for farmers [193].

Environmental factors affecting soil microorganisms include temperature, sugar content, carbon dioxide levels, aeration, and native microflora and micro and meso-fauna [132]. Additionally, vesicular arbuscular mycorrhizae respond favorably under elevated carbon dioxide conditions [76,199]. Most of these local environmental conditions could be manipulated and maintained with a smart field system that utilizes the integration of soil sensors with subsurface, precision delivery technologies. Such a system would facilitate the integration of precision agrochemical inputs, microbial fertilization (i.e., biofertilization) and pest control (e.g., biological pest control). Development of this technology-based system approach to soil management through precision input delivery represents a unique opportunity to better homogenize plant-soil environments (e.g., rhizosphere, rhizoplane, and mycorrhizosphere) [60]. Such delivery systems could be used to overcome field-level variabilities (e.g., optimization of soil $\mathrm{pH}$, water content, structure, oxygen levels, and nutrient concentrations) [88] while advancing the development of beneficial microbial-based crop rotation systems that focus on consortia-level functionality [60] (e.g., production of 1-aminocyclopropane-1-carboxylate deaminase to reduce plant ethylene levels) [166].

Microbial fertilization (biofertilization) and manipulation of rhizosphere microorganisms by inputs of carbohydrates, carboxylic acids, and amino acids could be utilized to promote specific plant-microbial associations [200]; subsidizing or replacing plant organic compound exudation (e.g., using trehalose and sucrose). External introduction of these compounds may help to establish a "biased rhizosphere" supporting the establishment of specific plant-microbial associations through the modification of rhizospheric chemistry [90]. Such utilization of microbial growth-promoting substances has already been demonstrated in soilless growing media to improve water retention and to enhance wilting resistance of muskmelon transplants [200]. Though the specificity of plant exudates for the attraction and establishment of particular microbial consortia represent a complex challenge for microbial fertilization [41], development of commercially viable microbial-based inputs (e.g., biological nitrification inhibitors) could be used to improve crop fertilizer-use efficiencies [143], increase crop water-use efficiencies, and reduce greenhouse gas (e.g., nitrous oxide) emissions [94] while sustainably maintaining or enhancing crop yields.

Negative impacts of monoculture practices (lack of crop production diversity) are a significant modern agricultural issue; with maize, soybean, and wheat representing over two-thirds of all crops planted each year in the United States [53]. Monoculture production exacerbates the buildup of antagonistic soil-microorganisms; leading to increased instances of root infection, a decreased ability to compete with weeds, and reduced overall yields [53]. Development of a smart field platform could be used to enhance the technological capacity for precision management of water and nutrients through the top soil profile to foster uniform development of root architecture, improve crop rotation and tillage management efficacies (i.e., low or no-tillage production systems can save up to $75 \%$ in fuel costs) [53] and reduce external agricultural inputs [64]. Outcomes from such an approach to agricultural research and management will lead to improvements in the quality of degraded soil through re-establishment of beneficial microbial communities (e.g., accelerating naturally slow, non-linear ecosystem reclamation processes through precision soil fertility management) and reduction of greenhouse gas emissions while enhancing plants' capability to economically utilize inputs [22,115] 
and supporting the study of interactions between cultural practices, soil amendments (e.g., the positive and negative impacts of chemical fertilizers and pesticides) [64], and crop rotations on soil, microbial, and plant health [41].

A technologically advanced smart field platform may also be utilized for the field-level establishment and promotion of plant propagules primed via biotization. Biotization is defined as "the metabolic response of in vitro grown plant material to microbial inoculant(s) which promote developmental and physiological changes that enhance biotic and abiotic stress resistance in subsequent plant progeny [76]." Benefits of biotization include increased growth rates [82,201], enhanced disease [74,202,203] and stress resistance [74,204], sturdier root systems with greater biomass and root hair formation [64,74,83,126], increased leaf hair formation [65], and greater lignification of xylem vessels [65,74]. Specific examples of beneficial biotization include increased root nodule production in red clover [96], enhanced potato tuber production [191], greener potato plantlets with higher levels of cytokinins [78], and elevated chilling tolerance (due to increases in total soluble sugars and maintenance of high net photosynthesis) [205,206]. Additionally, bacterized plantlets have been found to possess increased levels of phenylalanine ammonia lyase and free phenolics (compounds associated with enhanced resistance to environmental stresses and pathogen attack) [60,74]. However, benefits of bacterization at field-level are typically reduced by high precipitation or severe drought [132]; adverse environmental factors that could be mitigated through the utilization of a technology-driven precision input agriculture management system.

Furthermore, the proposed smart field technology platform could be used to provide insight into signal transduction and recognition mechanisms in plant-microbe and microbe-microbe interactions under varying environmental conditions [41,132] (e.g., influences of geographic location, soil type, and soil parameters on microorganism consortia establishment and survival) [109,207], the molecular determinants of plant and microbial nutrient sequestration, the classification of signal molecules involved with nutrient sensing, and potential methods for rapid identification of beneficial and pathogenic rhizospheric microorganism colonization (i.e., development of simple diagnostic tools) [41]. Additionally, research and testing focused on development of artificial plant and microbial exudate mixtures for field-level priming (e.g., low-toxic chemicals that mimic small interfering RNAs) [208] could facilitate greater exploration and understanding of the volatile-mediated effects of bacteria on plants [84]. The outcome of research facilitated through the utilization of a technologically advanced and versatile smart field platform will lead to improved knowledge of the interactive mechanisms between atmosphere, hydrosphere, and biosphere [193]; thereby laying the foundation for development of cutting edge agricultural systems that incorporate advanced technologies and low-input production management based on soil and plant biology that targets precision delivery of inputs synchronized with growth stages of crop plants.

\subsection{Smart Field Technology Platform: Interdisciplinary Opportunities}

In the coming years we will see unprecedented investment in sustainable technologies and practices that impact critical resources such as energy, food, and water. An obvious intersection and opportunity to positively manage and impact these resources is in agriculture, where production of sustainable energy crops and regional foods must be managed in ways that improve water quality, as compared to 
traditional agriculture methods which are typically not sustainable and may negatively affect water resources. Moving forward, it can be argued that the infusion of engineering technologies is needed to fully realize the economic and social benefits promised by sustainable practices-especially since many agriculture activities rely on limited or dated technologies.

One opportunity for interdisciplinary research in smart fields is the development of the next-generation technology platforms that marry the best-of-breed in agriculture, human-computer interaction, and advanced engineering (see Figure 1).

Figure 1. The interacting components of the next-generation, sustainable agriculture technology platform. Research in the green area addresses information flow, accessibility, and areas of human-computer interaction. Research in the blue areas represent advanced agricultural irrigation practices [190]. The red areas represent engineering opportunities to integrate unmanned vehicles in support of data collection, monitoring and intervention.

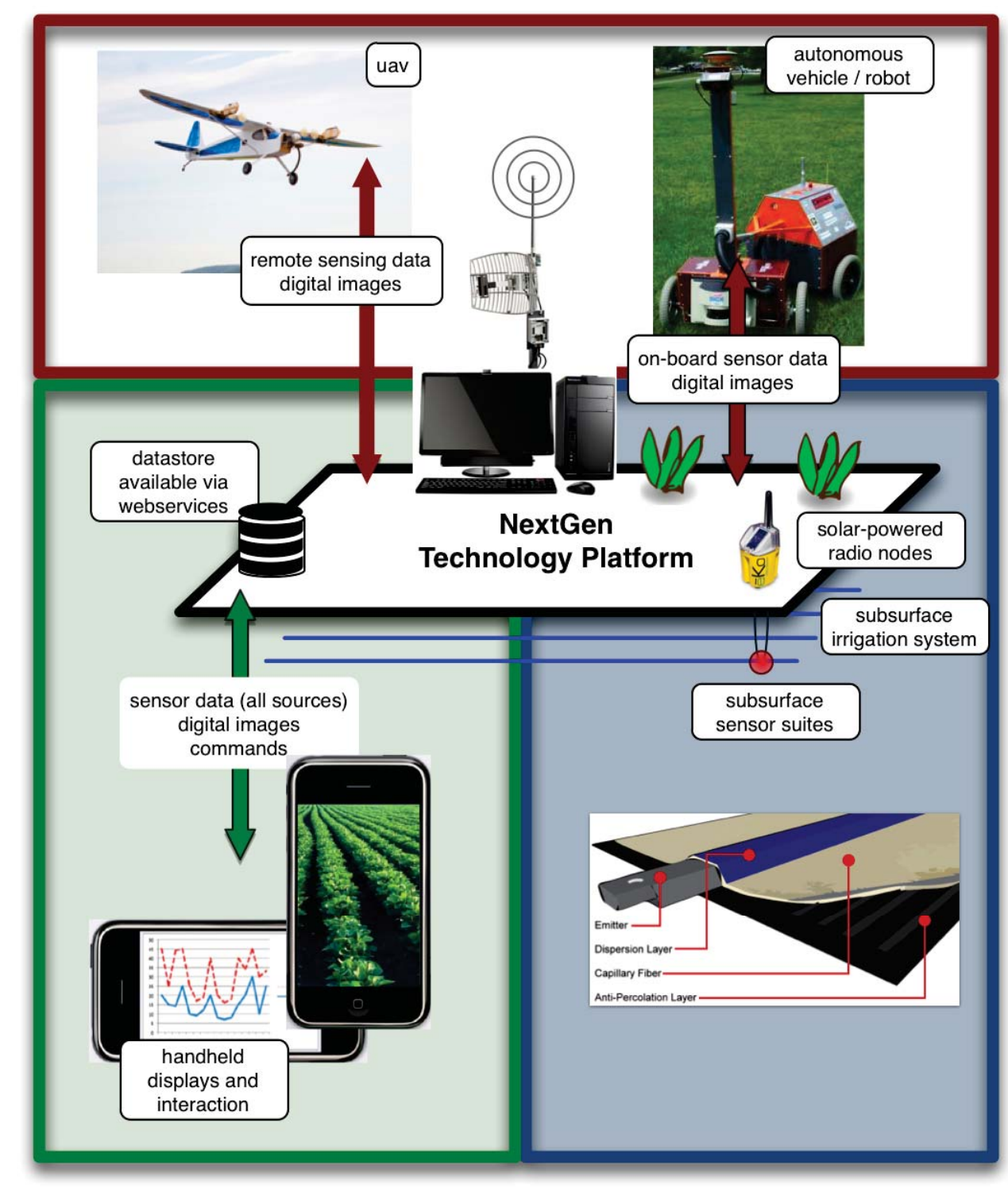


The platform conceptually contains three broad areas of expertise: advanced agriculture, human-computer-interaction, and engineering. In the most general sense, the advanced agricultural research employs rhizosphere-, ground vehicle-, and aerial vehicle-based sensor suites to precisely manage the rhizosphere while monitoring (in real-time) soil and plant health. Fixed position sensor nodes could be integrated with autonomous ground- and aerial-based sensor suites to non-destructively monitor abiotic and biotic crop stressors that affect crop growth and health (e.g., track and monitor airborne plant pathogens) [209] through the utilization of image analysis equipment and techniques (e.g., multispectral, hyperspectral, and thermography). Remote monitoring opportunities include canopy height measurements [210], crop water status monitoring [211], quantification of photosynthetic efficiencies [212-214], detection, identification [215], and monitoring of disease progress [216] and herbaceous damage [217]. The availability of such data in real-time will allow for quick intervention (treatment of "hot spots") thus mitigating plant stress and reducing the potential for the spread of disease/insects and yield losses. Fertilizer, water and air supply can also be adjusted to developmental stages of the plant, further enhancing inputs efficacy and reducing environmental impacts and cropping costs.

Genetically-based microbial profiling allows microbial population dynamics to be linked to soil type and farming inputs and outputs as well as to distinguish between active and dormant bacteria [218,219]. Results of this work can be leveraged to drive a technology-based input delivery system, to provide, water, mineral nutrients, microbial inoculants, crop protection chemicals, gases (i.e., $\mathrm{O}_{2}$, air or $\mathrm{H}_{2}$ ) and organic nutrients (i.e., sugars and/or signal molecules) that preferentially feed soil beneficial microbes, creating healthy rhizospheres and plant stands. Using this platform, such techniques can be applied prior to planting to reduce soil-borne disease pressures after establishment.

Additionally, smart field data collection and analysis (e.g., soil, plant, and environmental monitoring) could provide real-time ecophysiological information that, combined with genetic mapping, would facilitate the development of robust crop systems biology models for predicting and monitoring crop growth and yield performance under varying environmental conditions at the field-level. Ogata [220] defines system dynamics as "the mathematical modeling of dynamic systems and response analyses of such systems with a view toward understanding the dynamic nature of each system and improving the system's performance." Though system dynamics is typically recognized as an engineering tool, plant scientists are beginning to utilize this technique for the dissection and quantification of crop biology through the combining of data-driven, ecophysiological modeling (e.g., temperature and photoperiod) [221] and genetic mapping [222]. This new approach to crop modeling highlights the transition from tradition crop physiological modeling (i.e., whole plant population interactions with abiotic environments) to development of advanced, data driven crop biology models that, in addition to ecophysiological data, integrate molecular biology and molecular genetics [221]. Yin and Struik [222] posit that development of a crop systems biology approach for quantification of genotype-environment interactions will guide crop level understanding of functional genomics and provide greater insights into intra- and inter-plant competition while assisting the incorporation of biological mechanisms into existing crop models. It is hoped that this approach will not only facilitate data synthesis and modeling of physiological plant responses, but also encourage the development of novel hypotheses and methods that facilitate research into, and understanding of, crop 
biological systems from the micro- to the macro-level (e.g., biological scaling) [223]. Such approach can significantly contribute to plant selection and breeding for specific edaphic conditions [224].

An emphasis on human-computer interaction (HCI) is needed to ensure that smart fields do not become overwhelming and technologically confusing for farm managers. The technology platform employs concepts of location-based network services (LBNS), GPS and mobile broadband internet to allow farm managers with handheld phones to interact with sensor suites and advanced information placed throughout the plot. This approach allows software components to reside on individual handhelds (as opposed to secondary servers), independent of any other computing platforms. As such, each handheld and sensor suite can act as independent agents, connecting with each other only when in proximity to each other. This strategy also simplifies maintenance and troubleshooting during application phases - since all software functionality is self-contained on each individual handheld. More advanced concepts include the integration of mesh networks, cellular networks, or wi-fi clouds to support sophisticated communication between sensors, as well as more advanced data mining, analyses, and visualization (e.g., temporal 3D contour plots and GIS overlays).

All data are available via web services so that both handhelds and stationary desktop computers can make real-time requests from sensor suite data. The sensor suite's microprocessor retrieves the latest data from the sensors and formats them into a webpage - available to farm managers on-the-go, agriculture office computers and even teachers and students in the classrooms. In this platform, all users access webpage containing real-time information streaming from particular sensors of interest.

The novelty (and power) of this approach is that by employing LBNS (see [225]) via handhelds, farm managers are able to cognitively integrate and associate specific soil parameters (shown in real-time on the handheld) with the visual appearance of the plant - noting for example that the wilted leaves could be a result of low soil moisture-something that in the past would have to be conjectured or heuristically determined.

Advanced engineering research can further enhance the technology platform, for example, by employing real-time imaging modeling techniques to model and monitor plant growth stages. Images are obtained via autonomous vehicle(s) (on ground and/or aerial), and then processed to determine plant stage. This method allows the extension of precision delivery, beyond simply "space" and into "time". That is, enabling automated delivery of various fertilizers and supplements throughout an individual plant's lifecycle. Moreover, these image/vision analysis techniques are used to assist in soil sensor fusion and data integration. Large amounts of spatial and temporal data about the soil's health are condensed into meaningful data that are presented spatially via handheld mobile displays; employing Augmented Reality overlay techniques to perceptually attach digital information to actual crops. Specifically, one can imagine a scenario where a farm manager takes a digital photo of a plot and then views that same photo with additional information overlaid onto the photo. Conceptually, the photo is sent via network to visual analysis software agents where a spatial model is created (using photographs and stored spatial models) and married with geo-located real-time soil data. The information is then rendered on top of the photograph and displayed to the farm manager. These customized displays can be easily understood and acted upon by the farm manager.

The smart field platform can also utilize autonomous robots that will "work in the field" and facilitate sustainable agriculture through precision delivery of inputs. These autonomous robots can plug in to the technology platform (Figure 1), and provide additional communication, sensor and 
digital image capabilities supporting digital image capture to serve as input to visual/image modeling and visualization; digital image analyses of plants including assessing plant health and growth stages; identifying diseases and conditions on a plant-by-plant basis, and generating yield estimates; polling of in-ground and above-ground soil sensors, and identifying potential problem areas to further sample; precision delivery of pesticides or other interventions on an "as-needed" or "just-in-time" basis as determined by soil-based and/or on-board sensor data.

\section{Concluding Remarks}

The elements of the proposed technology platform can be utilized either independently, or integrated, depending on the socioeconomic realities of the farming site/community/region, etc. [226]. These can range from a small-scale subsistent farming (e.g., in water deficient areas of the developing world where subsurface irrigation tape can be connected to a water bucket for uniform delivery of water and nutrients to the crop root zone) through large scale subsurface irrigation practices already in use (e.g., in the production of cotton — in [227] and [228]) to futuristic, sophisticated "smart field" systems that will allow for precise micro-delivery of inputs into the plant root zone based on the availability of real-time soil data (such as moisture, mineral/organic nutrient, oxygen, carbon dioxide, $\mathrm{N}_{2} \mathrm{O}$ and ethylene content, $\mathrm{pH}$, and potentially others) collected with sensor nodes that provide information on the biology of the air (aerial movement of pathogens), soil (microbial community dynamics) and plant (developmental stage, nutrition and health status). Progress in sensor technology, data transmission, their collection and processing capacity, and development of inexpensive next generation DNA sequencing technologies [229] that can deliver fast results on microbial population dynamics in the field will determine the speed, and the level of precision with which we can conduct research and create frugal input management practices that enhance soil, plant, and potentially, human health.

\section{Acknowledgments}

Support for this work was provided by the Institute for Critical Technology and Applied Science (ICTAS) Doctoral Scholars Graduate Assistantship, awarded to J. Weekley, and an ICTAS Grand Challenge Research project awarded to J. Gabbard, C. Gabbard and J. Nowak.

\section{References}

1. Eswaran, H.; Lal, R.; Reich, P.F. Land degradation: An overview. In Responses to Land Degradation; Bridges, E.M., Hannam, I.D., Oldeman, L.R., Pening de Vries, F.W.T., Scherr, S.J., Sompatpanit, S., Eds.; Science Publishers Inc.: Enfield, NH, USA, 2001; pp. $20-35$.

2. Smith, P.; Martino, D.; Cai, Z.; Gwary, D.; Janzen, H.; Kumar, P.; McCarl, B.; Ogle, S.; O'Mara, F.; Rice, C.; et al. Greenhouse gas mitigation in agriculture. Philos. Trans. R. Soc. B Biol. Sci. 2008, 363, 789-813.

3. Tilman, D.; Cassman, K.G.; Matson, P.A.; Naylor, R.; Polasky, S. Agricultural sustainability and intensive production practices. Nature 2002, 418, 671-677.

4. Sutton, M.A.; Oenema, O.; Erisman, J.W.; Leip, A.; van Grinsven, H.; Winiwarter, W. Too much of a good thing. Nature 2011, 472, 159-161. 
5. Matson, P.A.; Naylor, R.; Ortiz-Monasterio, I. Integration of environmental, agronomic, and economic aspects of fertilizer management. Science 1998, 280, 112-115.

6. Postel, S.L. Water for food production: Will there be enough in 2025? Bioscience 1998, 48, 629.

7. Cassman, K.G. Ecological intensification of cereal production systems: Yield potential, soil quality, and precision agriculture. Proc. Natl. Acad. Sci. USA 1999, 96, 5952-5959.

8. Smith, K.A.; Ball, T.; Conen, F.; Dobbie, K.E.; Massheder, J.; Rey, A. Exchange of greenhouse gases between soil and atmosphere: Interactions of soil physical factors and biological processes. Eur. J. Soil Sci. 2003, 54, 779-791.

9. Galloway, J.N.; Townsend, A.R.; Erisman, J.W.; Bekunda, M.; Cai, Z.C.; Freney, J.R.; Martinelli, L.A.; Seitzinger, S.P.; Sutton, M.A. Transformation of the nitrogen cycle: Recent trends, questions, and potential solutions. Science 2008, 320, 889-892.

10. McKenzie, V.J.; Townsend, A.R. Parasitic and infectious disease responses to changing global nutrient cycles. EcoHealth 2007, 4, 384-396.

11. Lafferty, K.D. How should environmental stress affect the population dynamics of disease? Ecol. Lett. 2003, 6, 654-664.

12. Howarth, R.W.; Boyer, E.W.; Pabich, W.J.; Galloway, J.N. Nitrogen use in the united states from 1961 to 2000 and potential future trends. Ambio 2002, 31, 88-96.

13. Tilman, D.; Fargione, J.; Wolff, B.; D’Antonio, C.; Dobson, A.; Howarth, R.; Schindler, D.; Schlesinger, W.H.; Simberloff, D.; Swackhamer, D. Forecasting agriculturally driven global environmental change. Science 2001, 292, 281-284.

14. Sutton, M.A.; Howard, C.M.; Erisman, J.W.; Billen, G.; Bleeker, A.; Grennfelt, P.; van Grinsven, H.; Grizzetti, B. The European Nitrogen Assessment; Cambridge University Press: Cambridge, UK, 2011; p. 664.

15. Day, W. Engineering advances for input reduction and systems management to meet the challenges of global food and farming futures. J. Agric. Sci. 2011, 149, 55-61.

16. Cole, C.V.; Duxbury, J.; Freney, J.; Heinemeyer, O.; Minami, K.; Mosier, A.; Paustian, K.; Rosenberg, N.; Sampson, N.; Sauerbeck, D.; et al. Global estimates of potential mitigation of greenhouse gas emissions by agriculture. Nutr. Cycl. Agroecosys. 1997, 49, 221-228.

17. Hou, A.X.; Chen, G.X.; Wang, Z.P.; van Cleemput, O.; Patrick, W.H. Methane and nitrous oxide emissions from a rice field in relation to soil redox and microbiological processes. Soil Sci. Soc. Am. J. 2000, 64, 2180-2186.

18. United States Environmental Protection Agency. Nitrous Oxide Emissions. Available online: http://www.epa.gov/nitrousoxide/scientific.html (accessed on 1 October 2012).

19. Forster, P.; Ramaswamy, V.; Artaxo, P.; Berntsen, T.; Betts, R.; Fahey, D.; Haywood, J.; Lean, J.; Lowe, D.; Myhre, G.; et al. Changes in atmospheric constituents and in radiative forcing. In Climate Change 2007: The Physical Science Basis: Contribution of Working Group I to the Fourth Assessment Report of the Intergovernmental Panel on Climate Change; Solomon, S., Qin, D., Manning, M., Chen, Z., Marquis, M., Averyt, K., Tignor, M., Miller, H., Eds.; Cambridge University Press: Cambridge, UK, 2007; pp. 129-234.

20. Dalal, R.C.; Wang, W.; Robertson, G.P.; Parton, W.J. Nitrous oxide emission from Australian agricultural lands and mitigation options: A review. Soil Res. 2003, 41, 165-195.

21. Daily, G.C. Ecology: The value of nature and the nature of value. Science 2000, 289, 395-396. 
22. Khan, M.S.; Zaidi, A.; Wani, P.A. Role of phosphate solubilizing microorganisms in sustainable agriculture-A review. In Sustainable Agriculture; Lichtfouse, E., Navarrete, M., Debaeke, P., Véronique, S., Alberola, C., Eds.; Springer: Amsterdam, The Netherlands, 2009; pp. 551-570.

23. Postel, S.L.; Daily, G.C.; Ehrlich, P.R. Human appropriation of renewable fresh water. Science 1996, 271, 785-788.

24. Gordon, L.J.; Steffen, W.; Jonsson, B.F.; Folke, C.; Falkenmark, M.; Johannessen, A. Human modification of global water vapor flows from the land surface. Proc. Natl. Acad. Sci. USA 2005, 102, 7612-7617.

25. Wallace, J.S. Increasing agricultural water use efficiency to meet future food production. Agric. Ecosyst. Environ. 2000, 82, 105-119.

26. Alizadeh, A. Status of Agricultural Water Use in Iran. In Water Conservation, Reuse, and Recycling: Proceeding of an Iranian American Workshop; National Academies Press: Washington, DC, USA, 2005; pp. 94-105.

27. Barnett, T.P.; Pierce, D.W. When will lake mead go dry? Water Resour. Res. 2008, 44, W3201.

28. Oki, T.; Kanae, S. Global hydrological cycles and world water resources. Science 2006, 313, 1068-1072.

29. Walker, W.R. Surface Irrigation: Theory and Practice; Prentice-Hall: Englewood Cliffs, NJ, USA, 1987; p. 386.

30. Kay, M. Surface Irrigation: Systems and Practice; Cranfield Press: Cranfield, UK, 1986; p. 142.

31. Foley, J.A.; DeFries, R.; Asner, G.P.; Barford, C.; Bonan, G.; Carpenter, S.R.; Chapin, F.S.; Coe, M.T.; Daily, G.C.; Gibbs, H.K.; et al. Global consequences of land use. Science 2005, 309, $570-574$.

32. Lymphatic Filariasis Elimination Program. The Cater Center Web site. Available online: http://www.cartercenter.org/health/lf/index.html (accessed on 25 September 2012).

33. Malaria Control Program. The Cater Center Web site. Available online: http://www.cartercenter. org/health/malaria_control/index.html (accessed on 25 September 2012).

34. Schistosomiasis Control Program. The Cater Center Web site. Available online: http://www. cartercenter.org/health/schistosomiasis/index.html (accessed on 25 September 2012).

35. Ward, F.A.; Pulido-Velazquez, M. Water conservation in irrigation can increase water use. Proc. Natl. Acad. Sci. USA 2008, 105, 18215-18220.

36. Erisman, J.W. How a century of ammonia synthesis changed the world. Nat. Geosci. 2008, 1, 636-639.

37. Food and Agriculture Organization of the United Nations Web site. Available online: http:// faostat.fao.org/ (accessed on 17 September 2012).

38. Mazoyer, M.; Roudart, L. A History of World Agriculture from the Neolithic Age to the Current Crisis; Monthly Review Press: New York, NY, USA, 2006; p. 528.

39. Biography: Luther Burbank, 1849-1926. Western Sonoma County Historical Society Web site. Available online: http://www.wschsgrf.org/articles/biographylutherburbank1849-1926 (accessed on 4 October 2012).

40. Jethro Tull (1674-1741). BBC History Web site. Available online: http://www.bbc.co.uk/history/ historic_figures/tull_jethro.shtml (accessed on 4 October 2012). 
41. Welbaum, G.E.; Sturz, A.V.; Dong, Z.M.; Nowak, J. Managing soil microorganisms to improve productivity of agro-ecosystems. Crit. Rev. Plant Sci. 2004, 23, 175-193.

42. Schils, R. How James Watt Invented the Copier: Forgotten Inventions of Our Great Scientists; Springer: New York, NY, USA, 2011; pp. 63-69.

43. Twigg, C.A.; Twigg, M.V. Centenary of the death of Justus von Liebig. J. Chem. Educ. 1973, 50, 273.

44. McNeill, J.R.; Winiwarter, V. Breaking the sod: Humankind, history, and soil. Science 2004, 304, 1627-1629.

45. Egli, T.; Zinn, M. The concept of multiple-nutrient-limited growth of microorganisms and its application in biotechnological processes. Biotechnol. Adv. 2003, 22, 35-43.

46. Bongaarts, J. Human population growth and the demographic transition. Philos. Trans. R. Soc. B Biol. Sci. 2009, 364, 2985-2990.

47. De Fraiture, C.; Molden, D.; Wichelns, D. Investing in water for food, ecosystems, and livelihoods: An overview of the comprehensive assessment of water management in agriculture. Agric. Water Manag. 2010, 97, 495-501.

48. Rudel, T.K.; Schneider, L.; Uriarte, M.; Turner, B.L.; DeFries, R.; Lawrence, D.; Geoghegan, J.; Hecht, S.; Ickowitz, A.; Lambin, E.F.; et al. Agricultural intensification and changes in cultivated areas, 1970-2005. Proc. Natl. Acad. Sci. USA 2009, 106, 20675-20680.

49. World Population Prospects: The 2010 Revision, Press Release 3 May 2011. Available online: http://esa.un.org/wpp/Documentation/publications.htm (accessed on 15 August 2012).

50. Tilman, D.; Balzer, C.; Hill, J.; Befort, B.L. Global food demand and the sustainable intensification of agriculture. Proc. Natl. Acad. Sci. USA 2011, 108, 20260-20264.

51. McNeill, J.R. Something New under the Sun: An Environmental History of the Twentieth-Century World, 1st ed.; Norton: New York, NY, USA, 2000; p. 421.

52. Pardey, P.G.; Beintema, N.M. Slow Magic: Agricultural R\&D a Century after Mendel; International Food Policy Research Institute: Washington, DC, USA, 2001; pp. 11-12.

53. Cook, R.J. Toward cropping systems that enhance productivity and sustainability. Proc. Natl. Acad. Sci. USA 2006, 103, 18389-18394.

54. Srinivasan, A. Handbook of Precision Agriculture: Principles and Applications; Food Products Press: New York, NY, USA, 2006; p. 683.

55. Robert, P.C. Precision agriculture: A challenge for crop nutrition management. Plant Soil 2002, 247, 143-149.

56. Virginia Tech Soil Testing Lab Web site. Available online: http://www.soiltest.vt.edu/ (accessed on 25 September 2012).

57. Christy, C.D. Real-time measurement of soil attributes using on-the-go near infrared reflectance spectroscopy. Comput. Electron. Agric. 2008, 61, 10-19.

58. LSU AgCenter Web site. Available online: www.LSUAgCenter.com (accessed on 11 October 2011).

59. Geonics Web site. Available online: http://www.geonics.com (accessed on 11 October 2011).

60. Sturz, A.V.; Christie, B.R.; Nowak, J. Bacterial endophytes: Potential role in developing sustainable systems of crop production. Crit. Rev. Plant Sci. 2000, 19, 1-30. 
61. Irrigation \& Water Technologies Pty. Ltd. Web site. Available online: www.kisss.com.au (accessed on 8 December 2012).

62. Irrigro Web site. Available online: www.irrigro.com (accessed on 8 December 2012).

63. Gabbard, J.; Gabbard, C.; Nowak, J. Enabling Sustainable Agriculture and Natural Resource Research and Education by Integrating Engineering Technology into Sustainable Practices; Annual Report-Project \#117789 for Virginia Tech Institute for Critical Technology and Applied Science (ICTAS): Blacksburg, VA, USA; Unpublished work, 2012.

64. Sturz, A.V.; Nowak, J. Endophytic communities of rhizobacteria and the strategies required to create yield enhancing associations with crops. Appl. Soil Ecol. 2000, 15, 183-190.

65. Frommel, M.I.; Nowak, J.; Lazarovits, G. Growth enhancement and developmental modifications of in vitro grown potato (Solanum tuberosum spp. Tuberosum) as affected by a nonfluorescent Pseudomonas sp. Plant Physiol. 1991, 96, 928-936.

66. Gochnauer, M.B.; McCully, M.E.; Labbe, H. Different populations of bacteria associated with sheathed and bare regions of roots of field-grown maize. Plant Soil 1989, 114, 107-120.

67. Vessey, J.K. Plant growth promoting rhizobacteria as biofertilizers. Plant Soil 2003, 255, 571-586.

68. Wilson, D. Endophyte-The evolution of a term, and clarification of its use and definition. Oikos 1995, 73, 274-276.

69. Bell, C.R.; Dickie, G.A.; Harvey, W.L.G.; Chan, J. Endophytic bacteria in grapevine. Can. J. Microbiol. 1995, 41, 46-53.

70. Kloepper, J.W. Plant growth-promoting rhizobacteria as biological control agents. In Soil Microbial Ecology: Applications in Agriculture and Environmental Management; Metting, F.B., Jr., Ed.; Marcel Dekker Inc.: New York, NY, USA, 1992; pp. 255-274.

71. Kim, S.; Lowman, S.; Hou, G.; Nowak, J.; Flinn, B.; Mei, C. Growth promotion and colonization of switchgrass (Panicum virgatum) cv. Alamo by bacterial endophyte Burkholderia phytofirmans strain PsJN. Biotechnol. Biofuels 2012, 5, 37; doi:10.1186/1754-6834-5-37.

72. Compant, S.; Mitter, B.; Colli-Mull, J.; Gangl, H.; Sessitsch, A. Endophytes of grapevine flowers, berries, and seeds: Identification of cultivable bacteria, comparison with other plant parts, and visualization of niches of colonization. Microb. Ecol. 2011, 62, 188-197.

73. Zilber-Rosenberg, I.; Rosenberg, E. Role of microorganisms in the evolution of animals and plants: The hologenome theory of evolution. FEMS Microbiol. Rev. 2008, 32, 723-735.

74. Nowak, J.; Asiedu, S.K.; Bensalim, S.; Richards, J.; Stewart, A.; Smith, C.; Stevens, D.; Sturz, A.V. From laboratory to applications: Challenges and progress with in vitro dual cultures of potato and beneficial bacteria. Plant Cell Tissue Organ Cult. 1998, 52, 97-103.

75. Da, K.; Nowak, J.; Flinn, B. Potato cytosine methylation and gene expression changes induced by a beneficial bacterial endophyte, Burkholderia phytofirmans strain PsJN. Plant Physiol. Biochem. 2012, 50, 24-34.

76. Nowak, J. Benefits of in vitro "biotization" of plant tissue cultures with microbial inoculants. In Vitro Cell. Dev. Biol. Plant 1998, 34, 122-130. 
77. Galleguillos, C.; Aguirre, C.; Barea, J.M.; Azcon, R. Growth promoting effect of two Sinorhizobium meliloti strains (a wild type and its genetically modified derivative) on a non-legume plant species in specific interaction with two arbuscular mycorrhizal fungi. Plant Sci. 2000, 159, 57-63.

78. Lazarovits, G.; Nowak, J. Rhizobacteria for improvement of plant growth and establishment. Hortscience 1997, 32, 188-192.

79. Fallik, E.; Sarig, S.; Okon, Y. Morphology and physiology of plant roots associated with Azospirillum. In Azospirillum/Plant Associations; Okon, Y., Ed.; CRC Press Inc.: Boca Raton, FL, USA, 1994; pp. 77-83.

80. Nowak, J.; Asiedu, S.K.; Lazarovits, G.; Pillay, V.; Stewart, A.; Smith, C.; Liu, Z. Enhancement of in Vitro Growth and Transplant Stress Tolerance of Potato and Vegetable Plantlets Co-cultured with a Plant Growth Promoting Pseudomonad Bacterium. In Proceedings of Ecophysiology and Photosynthetic in Vitro Cultures, Aix en Provence, France, 1-3 December 1995; Carre, F., Chagvardieff, P., Eds.; CEA: Aix en Provence, France, 1995; pp. 173-180.

81. Nowak, J.; Bensalim, S.; Smith, C.; Dunbar, C.; Asiedu, S.; Madani, A.; Lazarovits, G.; Northcott, D.; Sturz, A. Behaviour of plant material issued from in vitro tuberization. Potato Res. 1999, 42, 505-519.

82. Bensalim, S.; Nowak, J.; Asiedu, S.K. A plant growth promoting rhizobacterium and temperature effects on performance of 18 clones of potato. Am. J. Potato Res. 1998, 75, 145-152.

83. Pillay, V.K.; Nowak, J. Inoculum density, temperature, and genotype effects on in vitro growth promotion and epiphytic and endophytic colonization of tomato (Lycopersicon esculentum L.) seedlings inoculated with a pseudomonad bacterium. Can. J. Microbiol. 1997, 43, 354-361.

84. Blom, D.; Fabbri, C.; Connor, E.C.; Schiestl, F.P.; Klauser, D.R.; Boller, T.; Eberl, L.; Weisskopf, L. Production of plant growth modulating volatiles is widespread among rhizosphere bacteria and strongly depends on culture conditions. Environ. Microbiol. 2011, 13, 3047-3058.

85. Compant, S.; Nowak, J.; Coenye, T.; Clément, C.; Ait Barka, E. Diversity and occurrence of Burkholderia spp. in the natural environment. FEMS Microbiol. Rev. 2008, 32, 607-626.

86. Compant, S.; Clement, C.; Sessitsch, A. Plant growth-promoting bacteria in the rhizo- and endosphere of plants: Their role, colonization, mechanisms involved and prospects for utilization. Soil Biol. Biochem. 2010, 42, 669-678.

87. Ma, W.; Zalec, K.; Glick, B.R. Biological activity and colonization pattern of the bioluminescence-labeled plant growth-promoting bacterium Kluyvera ascorbata SUD165/26. FEMS Microbiol. Ecol. 2001, 35, 137-144.

88. Bonkowski, M. Protozoa and plant growth: The microbial loop in soil revisited. New Phytol. 2004, 162, 617-631.

89. Bais, H.P. The role of root exudates in rhizosphere interactions with plants and other organisms. Annu. Rev. Plant Biol. 2006, 57, 233-266.

90. Hartmann, A.; Schmid, M.; van Tuinen, D.; Berg, G. Plant-driven selection of microbes. Plant Soil 2009, 321, 235-257.

91. Topp, G.C.; Watt, M.; Hayhoe, H.N. Point specific measurement and monitoring of soil water content with an emphasis on TDR. Can. J. Soil Sci. 1996, 76, 307-316. 
92. Watt, M.; Silk, W.K.; Passioura, J.B. Rates of root and organism growth, soil conditions, and temporal and spatial development of the rhizosphere. Ann. Bot. 2006, 97, 839-855.

93. Jones, D.L.; Nguyen, C.; Finlay, R.D. Carbon flow in the rhizosphere: Carbon trading at the soil-root interface. Plant Soil 2009, 321, 5-33.

94. Richardson, A.; Barea, J.-M.; McNeill, A.; Prigent-Combaret, C. Acquisition of phosphorus and nitrogen in the rhizosphere and plant growth promotion by microorganisms. Plant Soil 2009, 321, 305-339.

95. Bloemberg, G.V.; Lugtenberg, B.J.J. Molecular basis of plant growth promotion and biocontrol by rhizobacteria. Curr. Opin. Plant Biol. 2001, 4, 343-350.

96. Sturz, A.V.; Christie, B.R.; Matheson, B.G.; Nowak, J. Biodiversity of endophytic bacteria which colonize red clover nodules, roots, stems and foliage and their influence on host growth. Biol. Fertil. Soils 1997, 25, 13-19.

97. Haichar, F.E.; Marol, C.; Berge, O.; Rangel-Castro, J.I.; Prosser, J.I.; Balesdent, J.; Heulin, T.; Achouak, W. Plant host habitat and root exudates shape soil bacterial community structure. ISME J. 2008, 2, 1221-1230.

98. Rudrappa, T.; Czymmek, K.J.; Pare, P.W.; Bais, H.P. Root-secreted malic acid recruits beneficial soil bacteria. Plant Physiol. 2008, 148, 1547-1556.

99. Van West, P.; Morris, B.M.; Reid, B.; Appiah, A.A.; Osborne, M.C.; Campbell, T.A.; Shepherd, S.J.; Gow, N.A.R. Oomycete plant pathogens use electric fields to target roots. Mol. Plant-Microbe Interact. 2002, 15, 790-798.

100. Schulz, S.; Dickschat, J.S. Bacterial volatiles: The smell of small organisms. Nat. Prod. Rep. 2007, 24, 814-842.

101. Raaijmakers, J.M.; Paulitz, T.C.; Steinberg, C.; Alabouvette, C.; Moenne-Loccoz, Y. The rhizosphere: A playground and battlefield for soilborne pathogens and beneficial microorganisms. Plant Soil 2009, 321, 341-361.

102. Compant, S.; Duffy, B.; Nowak, J.; Clement, C.; Barka, E.A. Use of plant growth-promoting bacteria for biocontrol of plant diseases: Principles, mechanisms of action, and future prospects. Appl. Environ. Microbiol. 2005, 71, 4951-4959.

103. Burr, T.J.; Schroth, M.N.; Suslow, T. Increased potato yields by treatment of seed-pieces with specific strains of Pseudomonas fluorescens and P. Putida. Phytopathology 1978, 68, 1377-1383.

104. Brown, M.E. Plant growth substances produced by micro-organisms of soil and rhizosphere. J. Appl. Microbiol. 1972, 35, 443-451.

105. Sitnikov, D.M.; Schineller, J.B.; Baldwin, T.O. Transcriptional regulation of bioluminesence genes from Vibrio fischeri. Mol. Microbiol. 1995, 17, 801-812.

106. Boller, T. Mechanisms involved in non-target effects of pesticides on soil-borne pathogens. In Pesticide Interactions in Crop Production: Beneficial and Deleterious Effects; Altman, J., Ed.; CRC Press: Boca Raton, FL, USA, 1993; pp. 281-301.

107. Mark, G.L. Transcriptome profiling of bacterial responses to root exudates identifies genes involved in microbe-plant interactions. Proc. Natl. Acad. Sci. USA 2005, 102, 17454-17459.

108. Berg, G.; Smalla, K. Plant species and soil type cooperatively shape the structure and function of microbial communities in the rhizosphere. FEMS Microbiol. Ecol. 2009, 68, 1-13. 
109. Fierer, N.; Jackson, R.B. The diversity and biogeography of soil bacterial communities. Proc. Natl. Acad. Sci. USA 2006, 103, 626-631.

110. Revsbech, N.P.; Pedersen, O.; Reichardt, W.; Briones, A. Microsensor analysis of oxygen and $\mathrm{pH}$ in the rice rhizosphere under field and laboratory conditions. Biol. Fertil. Soils 1999, 29, 379-385.

111. $\mathrm{Xu}, \mathrm{H}$. Soil-root interface water potential in sweet corn as affected by organic fertilizer and a microbial inoculant. In Nature Farming and Microbial Applications; Xu, H., Parr, J.F., Umemura, H., Eds.; Food Products Press: Binghamton, NY, USA, 2000; pp. 139-156.

112. Tavaria, F.K.; Zuberer, D.A. Effect of low $p \mathrm{O}_{2}$ on colonization of maize roots by a genetically altered Pseudomonas putida [PH6(L1019)]. Biol. Fertil. Soils 1997, 26, 43-49.

113. Wu, T.; Chellemi, D.O.; Graham, J.H.; Martin, K.J.; Rosskopf, E.N. Comparison of soil bacterial communities under diverse agricultural land management and crop production practices. Microb. Ecol. 2008, 55, 293-310.

114. Carney, K.M.; Matson, P.A. The influence of tropical plant diversity and composition on soil microbial communities. Microb. Ecol. 2006, 52, 226-238.

115. Jangid, K.; Williams, M.A.; Franzluebbers, A.J.; Schmidt, T.M.; Coleman, D.C.; Whitman, W.B. Land-use history has a stronger impact on soil microbial community composition than aboveground vegetation and soil properties. Soil Biol. Biochem. 2011, 43, 2184-2193.

116. Bloemberg, G.V. Simultaneous imaging of WCS365 populations expressing three different autofluorescent proteins in the rhizosphere: New perspectives for studying microbial communities. Mol. Plant-Microbe Interact. 2000, 13, 1170-1176.

117. Marschner, P.; Yang, C.H.; Lieberei, R.; Crowley, D.E. Soil and plant specific effects on bacterial community composition in the rhizosphere. Soil Biol. Biochem. 2001, 33, 1437-1445.

118. Berg, G. Plant-microbe interactions promoting plant growth and health: Perspectives for controlled use of microorganisms in agriculture. Appl. Microbiol. Biotechnol. 2009, 84, 11-18.

119. Andre, H.M.; Ducarme, X.; Lebrun, P. Soil biodiversity: Myth, reality or conning? Oikos 2002, 96, 3-24.

120. Odonnell, A.G.; Goodfellow, M.; Hawksworth, D.L. Theoretical and practical aspects of the quantification of biodiversity among microorganisms. Philos. Trans. R. Soc. Lond. Ser. B Biol. Sci. 1994, 345, 65-73.

121. Smith, K.P.; Handelsman, J.; Goodman, R.M. Genetic basis in plants for interactions with disease-suppressive bacteria. Proc. Natl. Acad. Sci. USA 1999, 96, 4786-4790.

122. Loper, J.E.; Kobayashi, D.Y.; Paulsen, I.T. The genomic sequence of Pseudomonas fluorescens Pf-5: Insights into biological control. Phytopathology 2007, 97, 233-238.

123. Jacobsen, B.J.; Zidack, N.K.; Larson, B.J. The role of bacillus-based biological control agents in integrated pest management systems: Plant diseases. Phytopathology 2004, 94, 1272-1275.

124. Long, S.R. Genes and signals in the rhizobium-legume symbiosis. Plant Physiol. 2001, 125, 69-72.

125. Harman, G.E.; Howell, C.R.; Viterbo, A.; Chet, I.; Lorito, M. Trichoderma speciesOpportunistic, avirulent plant symbionts. Nat. Rev. Microbiol. 2004, 2, 43-56.

126. Conn, K.L.; Nowak, J.; Lazarovits, G. A gnotobiotic bioassay for studying interactions between potatoes and plant growth-promoting rhizobacteria. Can. J. Microbiol. 1997, 43, 801-808. 
127. Liu, Z.; Pillay, V.; Nowak, J. In vitro culture of watermelon and cantaloupe with and without beneficial bacterium. Acta Hortic. 1995, 402, 58-60.

128. Wang, B.; Qiu, Y.L. Phylogenetic distribution and evolution of mycorrhizas in land plants. Mycorrhiza 2006, 16, 299-363.

129. Nagarajan, S. Abiotic tolerance and crop improvement. In Abiotic Stress Adaptation in Plants: Physiological, Molecular and Genomic Foundation; Pareek, A., Sopory, S.K., Bohnert, H.J., Govindjee, Eds.; Springer: Dordrecht, The Netherlands, 2010; pp. 1-11.

130. Smith, S.E.; Read, D.J. Mycorrhizal Symbiosis, 3rd ed.; Academic Press: New York, NY, USA, 2008; p. 523.

131. Buscot, F. What are soils? In Microorganisms in Soils: Roles in Genesis and Functions; Buscot, F., Varma, A., Eds.; Springer: New York, NY, UAS, 2005; pp. 3-16.

132. Nowak, J.; Shulaev, V. Priming for transplant stress resistance in in vitro propagation. In Vitro Cell. Dev. Biol. Plant 2003, 39, 107-124.

133. Harwood, R. A history of sustainable agriculture. In Sustainable Agricultural Systems; Edwards, C.A., Lal, R., Madden, P., Miller, R.H., House, G., Eds.; Soil and Water Conservation Society: Ankeny, IA, USA, 1990; pp. 3-19.

134. Shane, M.W.; Lambers, H. Cluster roots: A curiosity in context. Plant Soil 2005, 274, 101-125.

135. Jakobsen, I.; Abbott, L.K.; Robson, A.D. External hyphae of vesicular-arbuscular mycorrhizal fungi associated with Trifolium subterraneum L. New Phytol. 1992, 120, 371-380.

136. Barea, J.M.; Pozo, M.J.; Azcon, R.; Azcon-Aguilar, C. Microbial co-operation in the rhizosphere. J. Exp. Bot. 2005, 56, 1761-1778.

137. Bonfante, P. Plants, mycorrhizal fungi and endobacteria: A dialog among cells and genomes. Biol. Bull. 2003, 204, 215-220.

138. Toljander, J.F.; Lindahl, B.D.; Paul, L.R.; Elfstrand, M.; Finlay, R.D. Influence of arbuscular mycorrhizal mycelial exudates on soil bacterial growth and community structure. FEMS Microbiol. Ecol. 2007, 61, 295-304.

139. Garbaye, J. Helper bacteria-A new dimension to the mycorrhizal symbiosis. New Phytol. 1994, 128, 197-210.

140. Alphei, J.; Bonkowski, M.; Scheu, S. Protozoa, nematoda and lumbricidae in the rhizosphere of Hordelymus europeaus (poaceae): Faunal interactions, response of microorganisms and effects on plant growth. Oecologia 1996, 106, 111-126.

141. Kuikman, P.J.; Jansen, A.G.; Vanveen, J.A. ${ }^{15} \mathrm{~N}$-nitrogen mineralization from bacteria by protozoan grazing at different soil-moisture regimes. Soil Biol. Biochem. 1991, 23, 193-200.

142. Spiertz, J.H.J. Nitrogen, sustainable agriculture and food security: A review. Agron. Sustain. Dev. 2010, 30, 43-55.

143. Adesemoye, A.; Kloepper, J. Plant-microbes interactions in enhanced fertilizer-use efficiency. Appl. Microbiol. Biotechnol. 2009, 85, 1-12.

144. Brady, N.C.; Weil, R.R. The Nature and Properties of Soils, 14th ed.; Pearson Education: Upper Saddle River, NJ, USA, 2008; p. 965.

145. Ogunseitan, O. Microbial Diversity: Form and Function in Prokaryotes; Blackwell Publishing: Malden, MA, USA, 2005; p. 292. 
146. Hernandez, G. Biological nitrogen fixation and sustainable agriculture. In Nitrogen Fixation: Global Perspectives; Finan, T.M., O’Brian, M.R., Layzell, D.B., Vessey, J.K., Newton, W., Eds.; CABI Publishing: New York, NY, USA, 2002; pp. 339-340.

147. Malik, K.A.; Zafar, Y.; Bilal, R.; Azam, E. Use of ${ }^{15} \mathrm{~N}$ isotope dilution for quantification of $\mathrm{N}_{2}$ fixation associated with roots of kallar grass Leptochloa fusca (L.). Biol. Fertil. Soils 1987, 4, $103-108$.

148. Franche, C.; Lindstrom, K.; Elmerich, C. Nitrogen-fixing bacteria associated with leguminous and non-leguminous plants. Plant Soil 2009, 321, 35-59.

149. Okon, Y. Azospirillum as a potential inoculant for agriculture. Trends Biotechnol. 1985, 3, 223-228.

150. Van Berkum, P.; Bohlool, B.B. Evaluation of nitrogen fixation by bacteria in association with roots of tropical grasses. Microbiol. Rev. 1980, 44, 491-517.

151. Kouas, S.; Labidi, N.; Debez, A.; Abdelly, C. Effect of P on nodule formation and $\mathrm{N}$ fixation in bean. Agron. Sustain. Dev. 2005, 25, 389-393.

152. Chen, Y.P.; Rekha, P.D.; Arun, A.B.; Shen, F.T.; Lai, W.A.; Young, C.C. Phosphate solubilizing bacteria from subtropical soil and their tricalcium phosphate solubilizing abilities. Appl. Soil Ecol. 2006, 34, 33-41.

153. Smith, S.E.; Smith, F.A.; Jakobsen, I. Functional diversity in arbuscular mycorrhizal (AM) symbioses: The contribution of the mycorrhizal $\mathrm{P}$ uptake pathway is not correlated with mycorrhizal responses in growth or total P uptake. New Phytol. 2004, 162, 511-524.

154. Goldstein, A.H.; Rogers, R.D.; Mead, G. Mining by microbe. Nat. Biotechnol. 1993, 11, $1250-1254$.

155. Unno, Y.; Okubo, K.; Wasaki, J.; Shinano, T.; Osaki, M. Plant growth promotion abilities and microscale bacterial dynamics in the rhizosphere of lupin analysed by phytate utilization ability. Environ. Microbiol. 2005, 7, 396-404.

156. Tinker, P.B.; Nye, P.H. Solute Movement in the Rhizosphere; Oxford University Press: New York, NY, USA, 2000.

157. Jones, D.L.; Darrah, P.R. Role of root derived organic-acids in the mobilization of nutrients from the rhizosphere. Plant Soil 1994, 166, 247-257.

158. Wallace, R.J. Antimicrobial properties of plant secondary metabolites. Proc. Nutr. Soc. 2004, 63, 621-629.

159. Sakakibara, H. Cytokinins: Activity, biosynthesis, and translocation. Annu. Rev. Plant Biol. 2006, 57, 431-449.

160. Barazani, O.; Friedman, J. Is IAA the major root growth factor secreted from plant-growth-mediating bacteria? J. Chem. Ecol. 1999, 25, 2397-2406.

161. Patten, C.L.; Glick, B.R. Bacterial biosynthesis of indole-3-acetic acid. Can. J. Microbiol. 1996, 42, 207-220.

162. Leveau, J.H.J.; Gerards, S. Discovery of a bacterial gene cluster for catabolism of the plant hormone indole 3-acetic acid. FEMS Microbiol. Ecol. 2008, 65, 238-250.

163. Hartmann, H.T. Plant Propagation: Principles and Practices, 6th ed.; Prentice Hall: Upper Saddle River, NJ, USA, 1997; p. 770. 
164. Mañero, F.J.G.; Acero, N.; Lucas, J.A.; Probanza, A. The infuence of native rhizobacteria on European alder (Alnus glutinosa (L.) Gaertn.) growth. Plant Soil 1996, 182, 67-74.

165. Schmulling, T. New insights into the functions of cytokinins in plant development. J. Plant Growth Regul. 2002, 21, 40-49.

166. Glick, B.R. Modulation of plant ethylene levels by the bacterial enzyme ACC deaminase. FEMS Microbiol. Lett. 2005, 251, 1-7.

167. Arshad, M. Ethylene: Agricultural Sources and Applications; Kluwer Academic/Plenum Publishers: New York, NY, USA, 2002.

168. Shah, S.; Li, J.P.; Moffatt, B.A.; Glick, B.R. Isolation and characterization of ACC deaminase genes from two different plant growth-promoting rhizobacteria. Can. J. Microbiol. 1998, 44, 833-843.

169. Campbell, B.G.; Thomson, J.A. 1-aminocyclopropane-1-carboxylate deaminase genes from Pseudomonas strains. FEMS Microbiol. Lett. 1996, 138, 207-210.

170. Wang, C.X.; Knill, E.; Glick, B.R.; Defago, G. Effect of transferring 1-aminocyclopropane-1carboxylic acid (ACC) deaminase genes into Pseudomonas fluorescens strain CHA0 and its gaca derivative CHA96 on their growth-promoting and disease-suppressive capacities. Can. J. Microbiol. 2000, 46, 898-907.

171. Hao, Y.; Charles, T.C.; Glick, B.R. ACC deaminase from plant growth-promoting bacteria affects crown gall development. Can. J. Microbiol. 2007, 53, 1291-1299.

172. Toklikishvili, N.; Dandurishvili, N.; Vainstein, A.; Tediashvili, M.; Giorgobiani, N.; Lurie, S.; Szegedi, E.; Glick, B.; Chernin, L. Inhibitory effect of ACC deaminase-producing bacteria on crown gall formation in tomato plants infected by agrobacterium tumefaciens or A. vitis. Plant Pathol. 2010, 59, 1023-1030.

173. Cheng, Z.Y.; Park, E.; Glick, B.R. 1-aminocyclopropane-1-carboxylate deaminase from Pseudomonas putida UW4 facilitates the growth of canola in the presence of salt. Can. J. Microbiol. 2007, 53, 912-918.

174. Farwell, A.J.; Vesely, S.; Nero, V.; Rodriguez, H.; McCormack, K.; Shah, S.; Dixon, D.G.; Glick, B.R. Tolerance of transgenic canola plants (Brassica napus) amended with plant growth-promoting bacteria to flooding stress at a metal-contaminated field site. Environ. Pollut. 2007, 147, 540-545.

175. Bonaterra, A.; Ruz, L.; Badosa, E.; Pinochet, J.; Montesinos, E. Growth promotion of Prunus rootstocks by root treatment with specific bacterial strains. Plant Soil 2003, 255, 555-569.

176. Cook, R.J.; Baker, K.F. The Nature and Practice of Biological Control of Plant Pathogens; American Phytopathological Society: St. Paul, MN, USA, 1983; p. 539.

177. Lockwood, J.L. Biological control of soil-borne plant pathogens. In Relation of Energy Stress to Behaviour of Soil-borne Plant Pathogens and to Disease Development; Hornby, D., Ed.; CAB International: Wallingford, UK, 1990; pp. 197-214.

178. Duijff, B.J.; Meijer, J.W.; Bakker, P.; Schippers, B. Siderophoree-mediated competition for iron and induced resistance in the suppression of fusarium-wilt of carnation by fluorescent Pseudomonas spp. Neth. J. Plant Pathol. 1993, 99, 277-289.

179. Van Loon, L. Plant responses to plant growth-promoting rhizobacteria. Eur. J. Plant Pathol. 2007, 119, 243-254. 
180. Chen, C.; Bauske, E.M.; Musson, G.; Rodriguezkabana, R.; Kloepper, J.W. Biological-control of fusarium-wilt on cotton by use of endophytic bacteria. Biol. Control 1995, 5, 83-91.

181. Maurhofer, M.; Keel, C.; Schnider, U.; Voisard, C.; Haas, D.; Defago, G. Influence of enhanced antibiotic production in Pseudomonas fluorescens strain-CHA0 on its disease suppressive capacity. Phytopathology 1992, 82, 190-195.

182. Eriksson, A.; Anfora, G.; Lucchi, A.; Lanzo, F.; Virant-Doberlet, M.; Mazzoni, V. Exploitation of insect vibrational signals reveals a new method of pest management. PLoS ONE 2012, 7, e32954.

183. Bruinsma, M.; Kowalchuk, G.A.; van Veen, J.A. Effects of genetically modified plants on microbial communities and processes in soil. Biol. Fertil. Soils 2003, 37, 329-337.

184. Kowalchuk, G.A.; Bruinsma, M.; van Veen, J.A. Assessing responses of soil microorganisms to GM plants. Trends Ecol. Evol. 2003, 18, 403-410.

185. Fred, E.B.; Baldwin, I.L.; McCoy, E. Root Nodule Bacteria and Leguminous Plants; University of Wisconsin Madison: Madison, WI, USA, 1932; Volume 5, p. 343.

186. Phan Thi, C.; Tran Dang, D.; Tran Minh, H.; Nguyen Thanh, H.; Choudhury, A.T.M.A.; Kecskés, M.L.; Kennedy, I.R. Inoculant plant growth-promoting microorganisms enhance utilisation of urea-N and grain yield of paddy rice in southern vietnam. Eur. J. Soil Biol. 2009, 45, $52-61$.

187. Efficient Nutrient Use in Rice Production in Vietname Achieved Using Inoculant Biofertilisers. In Proceedings of a Project (SMCN/2002/073) Workshop, Hanoi, Vietnam, 12-13 October 2007; Kennedy, I.R., Choudhury, A.T.M.A., Kecskés, M.L., Rose, M.T., Eds.; ACIAR Proceedings: Hanoi, Vietnam, 2007; Volume 130.

188. Whipps, J.M.; McQuilken, M.P. Aspects of biocontrol of fungal plant pathogens. In Exploitation of Microorganisms; Jones, D.G., Ed.; Chapman \& Hall: London, UK, 1993; pp. 45-79.

189. Schroth, M.N.; Becker, J.O. Concepts of ecological and physiological activities of rhizobacteria related to biological control and plant growth promotion. In Biological Control of Soil-Borne Plant Pathogens; Hornby, D., Ed.; CAB International: Wallingford, UK, 1990; pp. 389-414.

190. Mark, G.L.; Murphy, J.; Cassells, A.C. Microbial characterisation and preparation of inoculum for in vitro mycorrhization of strawberry in autotophic culture. In Pathogen and Microbial Contamination Management in Micropropagation; Cassells, A.C., Ed.; Kluwer Academic Publishers: Dordrecht, The Netherlands, 1997; Volume 12, pp. 345-350.

191. Sturz, A.V. The role of endophytic bacteria during seed piece decay and potato tuberization. Plant Soil 1995, 175, 257-263.

192. Yachi, S.; Loreau, M. Biodiversity and ecosystem productivity in a fluctuating environment: The insurance hypothesis. Proc. Natil. Acad. Sci. USA 1999, 96, 1463-1468.

193. Lal, R. Soils and sustainable agriculture: A review. Agron. Sustain. Dev. 2008, 28, 57-64.

194. Irrigation \& Water Technologies Pty. Ltd. Web site. Available online: http://www.kisss.com.au/ (accessed on 8 December 2012).

195. Lamm, F.R. Advantages and Disadvantages of Subsurface Drip Irrigation. In Proceedings of International Meeting on Advances in Drip/Micro Irrigation, Puerto de La Cruz, Tenerife, Canary Islands, Spain, 2-5 December 2002; Instituto Canario de Investigaciones Agrarias: Canary Islands, Spain, 2002. 
196. Mazzei Web site. Available online: www.mazzei.net (accessed on 8 December 2012).

197. Bhattarai, S.P.; Pendergast, L.; Midmore, D.J. Root aeration improves yield and water use efficiency of tomato in heavy clay and saline soils. Sci. Hortic. 2006, 108, 278-288.

198. Rose, M.; Deaker, R.; Potard, S.; Tran, C.; Vu, N.; Kennedy, I. The survival of plant growth promoting microorganisms in peat inoculant as measured by selective plate counting and enzyme-linked immunoassay. World J. Microbiol. Biotechnol. 2011, 27, 1649-1659.

199. Bécard, G.; Piché, Y. Fungal growth stimulation by $\mathrm{CO}_{2}$ and root exudates in vesicular-arbuscular mycorrhizal symbiosis. Appl. Environ. Microbiol. 1989, 55, 2320-2325.

200. Welbaum, G.E.; Shen, Z.X.; Watkinson, J.I.; Wang, C.L.; Nowak, J. Priming soilless growing medium with disaccharides stimulated microbial biofilm formation, and increased particle aggregation and moisture retention during muskmelon transplant production. J. Am. Soc. Hortic. Sci. 2009, 134, 387-395.

201. Chanway, C.P. Inoculation of tree roots with plant growth promoting soil bacteria: An emerging technology for reforestation. For. Sci. 1997, 43, 99-112.

202. Sticher, L.; MauchMani, B.; Metraux, J.P. Systemic acquired resistance. Annu. Rev. Phytopathol. 1997, 35, 235-270.

203. Benhamou, N.; Kloepper, J.W.; QuadtHallman, A.; Tuzun, S. Induction of defense-related ultrastructural modifications in pea root tissues inoculated with endophytic bacteria. Plant Physiol. 1996, 112, 919-929.

204. Sharma, V.K.; Nowak, J. Enhancement of verticillium wilt resistance in tomato transplants by in vitro co-culture of seedlings with a plant growth promoting rhizobacterium (Pseudomonas sp. strain PsJN). Can. J. Microbiol. 1998, 44, 528-536.

205. Fernandez, O.; Theocharis, A.; Bordiec, S.; Feil, R.; Jacquens, L.; Clément, C.; Fontaine, F.; Barka, E.A. Burkholderia phytofirmans PsJN acclimates grapevine to cold by modulating carbohydrate metabolism. Mol. Plant-Microbe Interact. 2012, 25, 496-504.

206. Fernandez, O.; Vandesteene, L.; Feil, R.; Baillieul, F.; Lunn, J.; Clément, C. Trehalose metabolism is activated upon chilling in grapevine and might participate in Burkholderia phytofirmans induced chilling tolerance. Planta 2012, 236, 355-369.

207. Weller, D.M.; Raaijmakers, J.M.; Gardener, B.B.M.; Thomashow, L.S. Microbial populations responsible for specific soil suppressiveness to plant pathogens. Annu. Rev. Phytopathol. 2002, 40, 309-348.

208. Coombs, A. Seeds Inherit Memories of Enemies. The Scientist, 31 May 2012.

209. Techy, L.; Woolsey, C.A.; Schmale, D.G. Monitoring the spread of a plant pathogen in the lower atmosphere using unmanned aerial vehicles and a bouyancy-controlled weather balloon. In Aerospace Technology Conference and Exposition; SAE: Seattle, WA, USA, 2009.

210. Murakami, T.; Yui, M.; Amaha, K. Canopy height measurement by photogrammetric analysis of aerial images: Application to buckwheat (Fagopyrum esculentum Moench) lodging evaluation. Comput. Electron. Agric. 2012, 89, 70-75.

211. Luquet, D.; Bégué, A.; Vidal, A.; Clouvel, P.; Dauzat, J.; Olioso, A.; Gu, X.F.; Tao, Y. Using multidirectional thermography to characterize water status of cotton. Remote Sens. Environ. 2003, $84,411-421$. 
212. Grace, J.; Nichol, C.; Disney, M.; Lewis, P.; Quaife, T.; Bowyer, P. Can we measure terrestrial photosynthesis from space directly, using spectral reflectance and fluorescence? Glob. Change Biol. 2007, 13, 1484-1497.

213. Rascher, U.; Nichol, C.J.; Small, C.; Hendricks, L. Monitoring spatio-temporal dynamics of photosynthesis with a portable hyperspectral imaging system. Photogramm. Eng. Remote Sens. 2007, 73, 45-56.

214. Scharte, J.; Schon, H.; Weis, E. Photosynthesis and carbohydrate metabolism in tobacco leaves during an incompatible interaction with Phytophthora nicotianae. Plant Cell Environ. 2005, 28, 1421-1435.

215. Wen, C.; Guyer, D. Image-based orchard insect automated identification and classification method. Comput. Electron. Agric. 2012, 89, 110-115.

216. Lindenthal, M.; Steiner, U.; Dehne, H.W.; Oerke, E.C. Effect of downy mildew development on transpiration of cucumber leaves visualized by digital infrared thermography. Phytopathology 2005, 95, 233-240.

217. Zhao, Y.; He, Y.; Xu, X. A novel algorithm for damage recognition on pest-infested oilseed rape leaves. Comput. Electron. Agric. 2012, 89, 41-50.

218. Sessitsch, A.; Weilharter, A.; Gerzabek, M.H.; Kirchmann, H.; Kandeler, E. Microbial population structures in soil particle size fractions of a long-term fertilizer field experiment. Appl. Environ. Microbiol. 2001, 67, 4215-4224.

219. Sessitsch, A.; Howieson, J.G.; Perret, X.; Antoun, H.; Martínez-Romero, E. Advances in Rhizobium research. Crit. Rev. Plant Sci. 2002, 21, 323-378.

220. Ogata, K. System Dynamics, 4th ed.; Pearsons Education, Inc.: Englewood Cliffs, NJ, USA, 2004; p. 768.

221. Hay, R.; Porter, J. The Physiology of Crop Yield, 2nd ed.; Blackwell Publishing Ltd.: Oxford, UK, 2006; p. 314.

222. Yin, X.; Struik, P.C. Modelling the crop: From system dynamics to systems biology. J. Exp. Bot. 2010, 61, 2171-2183.

223. Yin, X.; Struik, P.C. Applying modelling experiences from the past to shape crop systems biology: The need to converge crop physiology and functional genomics. New Phytol. 2008, 179, 629-642.

224. Masuka, B.; Araus, J.L.; Das, B.; Sonder, K.; Cairns, J.E. Phenotyping for abiotic stress tolerance in miaze. J. Integr. Plant Biol. 2012, 54, 238-249.

225. Wang, S.; Min, J.; Yi, B. Location Based Services for Mobiles: Technologies and Standards. In Proceedings of IEEE International Conference on Communication (ICC), Beijing, China, 19-23 May 2008; pp. 35-38.

226. Moxley, T. Technology Takes Root at Virginia Tech's Catawba Sustainability Center "Smart Farm". The Roanoke Times, 29 July 2011.

227. Sij, J.W.; Bordovsky, D.G.; Jones, D.L.; Slosser, J.E. Utilizing subsurface drip irrigation and conservation tillage in cotton production systems. SRX Agric. 2010, 2010, 1-6. 
228. Camp, C.; Lamm, F.; Evans, R.; Phene, C. Subsurface Drip Irrigation-Past, Present, and Future. In Proceedings of the 4th Decennial National Irrigation Symposium, Phoenix, AZ, USA, 14-16 November 2000; pp. 14-16.

229. Metzker, M.L. Sequencing technologies_The next generation. Nat. Rev. Genet. 2009, 11, $31-46$.

(C) 2012 by the authors; licensee MDPI, Basel, Switzerland. This article is an open access article distributed under the terms and conditions of the Creative Commons Attribution license (http://creativecommons.org/licenses/by/3.0/). 